Accepted in Regional Science and Urban Economics, 2002

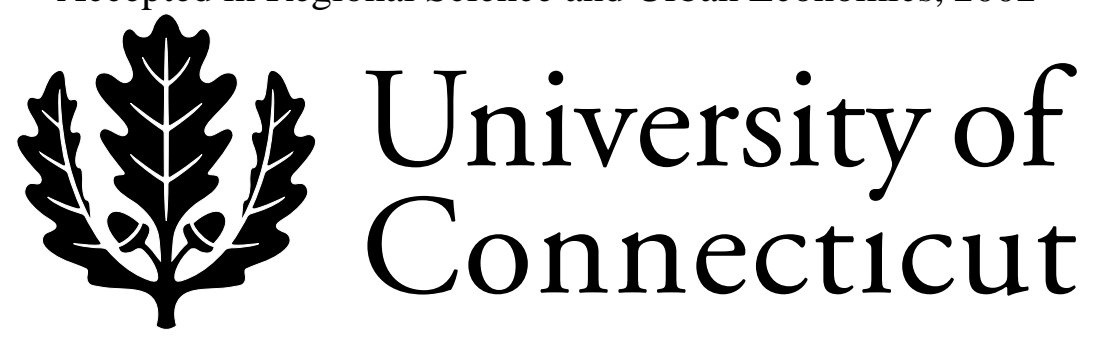

Department of Economics Working Paper Series

\title{
Racial Differences in Homeownership: The Effect of Residential Location
}

Yongheng Deng

University of Southern California

Stephen L. Ross

University of Connecticut

Susan M. Wachter

University of Pennsylvania

Working Paper 2002-05

July 2002

341 Mansfield Road, Unit 1063

Storrs, CT 06269-1063

Phone: (860) 486-3022

Fax: (860) 486-4463

http://www.econ.uconn.edu/ 


\begin{abstract}
The rate of homeownership among African-American households is considerably lower than white households in American urban areas. This paper examines whether racial differneces in residential location outcomes are among the factors that contribute to the large racial differences in homeownership rates in major US metropolitan areas. Based on the 1985 metropolitan sample of the American Housing Survey for Philadelphia, the paper does not find any evidence that existing racial differences in residential location in Philadelphia decrease the homeownership rate among African Americans. Rather, the empirical evidence suggests that African-American residential location outcomes are associated with lower than expected racial differences in homeownership. Therefore, after controlling for neighborhood, racial differences in homeownership are larger than originally believed, and the ability of racial differences in endowments to explain hoeownership differences is more limited.
\end{abstract}

Journal of Economic Literature Classification: R21, J15, D12

Keywords: Homeownership, Residential Location, Race, Credit Constraints, Equity Risk 


\section{INTRODUCTION}

Large racial differences in homeownership have been a source of considerable concern among policy makers because homeownership choice may influence wealth accumulation, labor market outcomes, and even children's educational outcomes. Racial differences in ownership rates may be affected by discrimination (Kain and Quigley, 1972), and extensive literatures examine the treatment of minorities by real estate broker and mortgage lenders (see, for example, Yinger (1992) and Munnell et. al. (1996)). At the same time, homeownership is associated with income and wealth. African-Americans have lower income and wealth than whites on average in the United States and that may also contribute to the racial differences in homeownership.

The role that income and wealth differences play in contributing to racial differences in homeownership is well documented. Wachter and Megbolugbe (1992) and Painter, Gabriel, and Meyers (2001a) examine the influence of racial differences in income on homeownership and the transition to homeownership, respectively. Both find that endowment differences explain a substantial portion of the racial differences. ${ }^{1}$ Duca and Rosenthal (1994) and Linneman and Wachter (1989) both find evidence that downpayment constraints have a substantial affect on homeownership and that credit constraints matter more than income in determining homeownership. ${ }^{2}$ Moreover, African-American homeownership rates were found to be significantly more responsive to changes in income (Wachter and Megbolugbe, 1992) and downpayment constraints (Gyourko, Linneman, and Wachter, 1999).

In most American metropolitan areas, many minorities are segregated into central cities, and the literature on racial segregation demonstrates that the level of observed segregation cannot be explained by income differences alone (Kain, 1976, 1992; Massey and Denton, 1993; DeRango, 1999). Gabriel and Rosenthal (1989) examine residential location choice in the Washington D.C. metropolitan area and find considerable evidence that the influences of socio-economic and demographic characteristics on location outcomes differ dramatically by race. ${ }^{3}$ Specifically, African-Americans are much less likely to alter their residential location based on changes in these characteristics. Similarly, Waddell (1992) finds for Dallas- 
Fort Worth that African-Americans are much less likely to suburbanize than whites as their incomes increase. $^{4}$

A reasonable question to ask is whether racial differences in residential location, reflected by the high and persistent level of segregation in American metropolitan areas, also contributes to the large racial differences in U.S. homeownership rates. One hypothesis is that racial differences in residential location may limit the homeownership opportunities of African-Americans to locations with higher equity risk, concentrated poverty, and an associated low value of homeownership. Therefore, racial segregation and housing market discrimination may aggravate racial differences in homeownership rates. On the other hand, equity risk, higher poverty rates, and other negative neighborhood attributes are expected to lower the price of owner-occupied housing. The incidence of homeownership among African-American households may actually increase in poor neighborhoods with low prices since many African-American households face substantial income and down payment constraints in purchasing housing. ${ }^{5}$ Moreover, discrimination in the market for owner-occupied housing often involves steering by real estate agents (Turner and Mickelsons, 1992), and as a result African-Americans that attempt to purchase owneroccupied housing may experience more segregation into poor quality neighborhoods than AfricanAmerican renters.

No scholarly study has attempted to answer this question. Painter, Gabriel and Meyers (2001b), Waddell (1992), and Gyourko, Linneman, and Wachter (1997) examine residential location and tenure choice in a single empirical model. Gyourko, Linneman, and Wachter (1997) find that AfricanAmericans are more likely to own in the central city in a national sample of households. Alternatively, Painter, Gabriel, and Meyers (2001b) find that minority renters who reside in Los Angeles county are more likely to transition to homeownership if they are moving to San Bernardino county as opposed to moving within Los Angeles. However, none of these papers examine whether differences in the attributes of specific residential locations actually influence the homeownership decision. ${ }^{6}$

In this paper, we provide such a test. We adopt a nested multinomial logit framework to estimate the decisions of residential location and tenure choice jointly using the metropolitan sample of the 
American Housing Survey for Philadelphia in 1985. In this model, tenure choice is modeled such that the homeownership decision is made while considering alternative subsets of residential location options. The resulting estimates are used to conduct policy simulations in order to assess the effect of demographic changes within the population and the effect of changes in residential location options on racial differences in homeownership rates. We do not find any evidence that residential location outcomes lower the rate of homeownership among African-American households in our sample. Rather, the estimates indicate that racial differences in the 1985 homeownership rate for the Philadelphia metropolitan area were limited or mitigated by racial differences in residential location. These findings raise doubts about the findings of previous studies that racial differences in homeownership may be predominantly explained by racial differences in endowments. After controlling for neighborhood, racial differences in homeownership are larger than originally believed, and endowments explain less than half of the larger homeownership differences.

The reader should not attempt to draw conclusions about why African-American households are concentrated in apparently lower quality residential locations. One possible conjecture is that AfricanAmerican households self-sort into poorer and lower quality neighborhoods in order to gain access to affordable owner-occupied housing. Alternative interpretations involving racial discrimination and steering, however, are equally plausible. The steering of African American household's into lower quality neighborhoods where housing price is low would have the same effect as self-sorting. A low price level among the restricted housing alternatives may mitigate downpayment and income constraints and lead to higher homeownership rates. In fact, if steering is more severe in the owner-occupied housing market, African-American owners might be concentrated in poor quality locations even if there were no endowment differences between white and African-American households.

The paper is organized as follows: Section 2 discusses the econometric models to be used in the test. Section 3 describes the data set. Section 4 presents empirical results from estimations and simulations. Section 5 is a brief conclusion. 


\section{METHODOLOGY}

Three tenure choice models are estimated: Model I, a basic model that controls for household characteristics and is comparable to traditional models, such as Linneman and Wachter (1989); Model II, which includes additional controls for the characteristics of each household's residential location, such as percent of households in poverty and percent of African-American, and assumes that decisions on residential location are exogenous to the tenure choice; and Model III, which considers the influence of residential location options on homeownership endogenously based on a nested multinomial logit specification.

While Model I allows us to compare our results with existing literatures, Models II and III are the focus of the paper and are intended to address the question of whether residential location choices contribute to or mitigate racial differences in homeownership. The results of model II in which residential location is assumed to be exogenous offer fairly straightforward interpretations. For example, if exposure to a high poverty rate location lowers homeownership for both whites and African-Americans, the fact that African-Americans reside in locations with higher poverty rates than white households contributes to racial differences in homeownership. However, the interpretation of the results from Model II is quite limited due to the assumption that residential location choice is exogenous in a household's tenure choice decision.

The nested multinomial logit model provides us with a coherent framework to test whether residential location options influence racial differences in homeownership. In Model III, a nested multinomial logit model, the value of specific residential location options depend upon whether a household resides in owner-occupied or rental housing. A household's tenure choice decision is made while accounting for the relative value of the residential location options simultaneously. In other words, we can view the nested decision making process as such that a decision on residential location is made while considering its potential impact on the home ownership decision. The structure of nested multinomial logit model is described below. 


\subsection{A Multinomial Model of Tenure and Residential Location Choice}

In the nested multinomial logit, a hierarchy of choices is established. However, at each choice level, an individual has full information on all opportunities that are available at the lower level choices. ${ }^{7}$ In this paper, tenure choice is specified as the upper level in the hierarchy, and residential location is the lower level in the hierarchy. ${ }^{8}$ The expected utility for a specific outcome may be decomposed into two pieces: one representing the utility arising directly from the tenure choice and the second representing the utility arising from a specific residential location conditional on tenure choice. Individual $i$ 's expected utility $(V)$ may be written as

$$
V_{i j t}=\alpha_{t} X_{i}+\beta_{t} Z_{j} X_{i}
$$

where $t$ indexes for tenure status such that $t=o$ if owner-occupied housing, or $t=r$ if rental housing; $\alpha_{o}$ for owner-occupied housing is the relationship between household characteristics $X$ and the propensity to reside in owner-occupied housing, $\alpha_{r}$ for rental housing is initialized to zero; $j$ is an index representing residential location; and $\beta_{t}$ is the relationship between the utility associated with a location and location attributes $Z$ for a given tenure outcome $t$. Note that the location attributes are interacted with household characteristics allowing the relationship between attributes and utility to vary by those household characteristics.

This empirical model provides a fairly complete description of the choice process and the mechanisms by which residential location choice may directly and indirectly shape the decision to own a home. The utility level associated with specific residential locations is captured by the second term in equation (1), and these levels vary across tenure choice and types of households. Differences in the value of specific attributes across tenure enter into the tenure choice equation. For example, some residential locations may be highly desirable to a household if they choose to rent, but less desirable if they choose to own. If such a household derives substantial benefits from homeownership, the household may forgo the highly desirable (conditional on renting) location and own in a very different place. 
Following McFadden (1978), the nested multinomial logit can be estimated consistently using a two-stage approach. In the first stage, the lower level choice (i.e., the residential location model) is estimated as a multinomial logit conditional on tenure choice. The representative utility of residential location choice for each individual household is then summarized by an "inclusive value" (it is also known as "inclusive utility") calculated based on the conditional estimates from the lower level choice models. In the second stage, the tenure choice model is estimated as a simple logit by adding the inclusive value obtained from the first stage estimation as an additional explanatory variable. Thus, the expected utility offered by the set of residential location options is accounted in the upper level tenure choice estimation.

The inclusive value is calculated as the log of the denominator on the conditional submodel for owner-occupied versus rental housing, such that $I_{i t}=\log \left[\sum_{j} \operatorname{Exp}\left[\hat{\beta}_{t} Z_{j} X_{i}\right]\right]$, where $I$ is the inclusive value, $Z$ represents residential location attributes, $\hat{\beta}$ is a vector of estimated coefficients for residential location attributes during the first state estimation, $X$ represents household characteristics over which coefficients may vary, $j$ indexes for alternatives of residential location choice, $t$ indexes for tenure status, and $i$ indexes for individual household.

The first stage residential location model involves choices among quite aggregated alternatives, which is often the case for multinomial choice models. Over aggregation can bias estimation results. Ben-Akiva and Lerman (1985) suggest including measures of alternative size and variation in the level of utility offered within an aggregated alternative. In the case of residential location choice, alternative size might reasonably be captured by the number of owner-occupied or rental housing units located within a spatial alternative.

The measurement of variation in utility level is a more difficult task. Under an assumption of free mobility across alternatives, differences in the utility level across location should be fully capitalized into land values. If so, no differences in utility level exist for equal agents in alternative locations, and the 
variation should be zero. On the other hand, utility differences may exist if they are only partially capitalized into land values. In this case, a correlation may exist between housing prices and the utility opportunities offered. Therefore, we use the variation in housing prices across alternatives to proxy for variation in the utility level provided.

\subsection{Household Level Control Variables}

Model I is a standard tenure choice model that controls for detailed household demographic characteristics as well as financial characteristics. The household demographic characteristics include family structure, age and education of the head of household and spouse if present. The household financial characteristics include both family income and the downpayment constraint in housing demand. Unconstrained housing demand as a homeowner is not observed if the household resides in rental housing or the household purchased less housing than desired due to a downpayment constraint. We construct a variable indicating whether a household is expected to face a downpayment constraint based on predicted assets and predicted optimal housing demand. Finally, for a robustness check, an instrument was developed for family income based on the estimation of employment and earnings regressions for each family member. The construction of the downpayment constraint and the family income variables are described in the Appendix. The Appendix also includes all estimations that are used to construct these variables. All coefficient estimates in the tenure choice model are allowed to vary by race.

\subsection{Location Attributes}

Models II and III include controls for the attributes of either the household's actual residential location or the residential location options that are available, respectively. The two models will include standard location attributes, such as the racial or income composition of a location or whether the location is located in the central city. In addition, the models will include two constructed variables in order to capture the overall quality or amenity level of each location and the equity risk associated with a location. Both variables are constructed using the estimates from standard house value and rental price models that control for the physical characteristics of the housing unit and location dummy variables. The estimated coefficients on the location dummy variables are price fixed effects. These fixed effects capture the price 
level after controlling for the physical quantity and quality of the housing unit. This fixed effect captures the market premium offered for housing in a given location and provides a proxy for the amenity level associated with that location. ${ }^{9}$ The ratio of the rental and owner-occupied price fixed effects are used as a proxy for equity risk. High equity risk should lower the value of owner-occupied housing relative to rents on similar properties since owners must bear the equity risk associated with the property. ${ }^{10}$ Model II simply includes these location attributes as linear regressors along with the household variables discussed above.

As shown in equation (1), Model III uses the location attributes to describe the expected utility associated with a specific residential location choice. The location attributes do not directly enter the second stage tenure choice equation; rather, these attributes are included in the residential location model and only enter the tenure choice model through the inclusive value. The location attributes are included directly in the multinomial logit specification plus the attributes are interacted with specific household characteristics: head of household race, marital status, and education level. Note that as with the tenure choice equation, all coefficient estimates are allowed to vary by race. For example, in the case of marital status, location attributes are interacted with a variable representing marital status if the head of household is white and a second variable representing marital status if the head of household if African-American.

Finally, Model III includes a third constructed variable in the first stage residential location choice. A gravity model is estimated and used to construct a measure of job access. The likelihood of choosing a given residential location is expected to decline with job access, but it is assumed that the homeownership choice is not directly influenced by job access. ${ }^{11}$ In addition, the importance of job access may depend upon the expected probability of employment for the household head and spouse, and the predicted probabilities of employment are interacted with job access in the residential location model. The Appendix presents a detailed discussion on each of these constructed variables, as well as the estimates that are used to construct these variables. 


\section{DATA DESCRIPTION}

The base sample for this analysis is the 1985 Metropolitan Area (Metro) sample of the American Housing Survey (AHS) for Philadelphia. The Metro sample of the AHS contains detailed housing characteristics and the location of the housing unit down to zones of approximately 100,000 in population. The city of Philadelphia is divided into 13 zones, and the rest of the metropolitan area is divided into 22 additional zones. It also contains information on family structure, family member demographics, and limited labor market variables for each member. The 1985 survey also included a commuting subsection in the survey, which collected the employment location of every employed family member using the same spatial zones that were used to record residential location. ${ }^{12}$

Specifically, the survey data provides information on characteristics of the reference person, characteristics of the reference person's spouse if married, whether the household includes relatives of the reference person, number of individuals in the household by age, family education level, ${ }^{13}$ family income, and information to be used to construct the downpayment constraint variable. As discussed earlier, the amenity/price fixed effect and the equity risk proxy are constructed for each zone by using the AHS to estimate separate hedonic price models for owner-occupied house value and monthly rent. These models control for a broad away of housing attributes as well as zone fixed effects.

In addition, the Department of Housing and Urban Development provided a list of 1980 census tracts that comprise each of the Metro sample zones, and this list was modified to account for changes in the census tract definitions between 1980 and 1990. Using this list and the Basic Summary Table Files (STF3) from the 1990 U.S. census, the following variables are generated for each Metro sample zones: percent residents in poverty, percent African-American households, number of owner-occupied and rental properties, and the coefficient of variation for house price and annual rent across all tracts in a zone. The zones were also used to construct a dummy variable for whether the household resided in the central city in 1985. Finally, the 1990 Census Transportation Planning Package (CTPP) is used to estimate the

gravity model for the AHS sample zones in the Philadelphia metropolitan area, see the Appendix. ${ }^{14}$ 
These tables were used to construct average travel time and commuting flows between the AHS sample zones, as well as total residential population and employment within each zone.

For all variables, the names, descriptions, and means by race are shown in Table 1 . In the sample, the racial difference in owner-occupancy is 18 percentage points. Of course, the differences may in part be explained by differences in household characteristics. In the sample, African-Americans have less education, lower marriage rates, lower family income, and are more likely to face a downpayment constraint. Residential location also varies by race as captured by the zone attributes. On average, African-Americans reside in locations with a higher percentage of African-American residents, a higher percentage of residents in poverty, lower overall amenity levels (as captured by lower quality adjusted price levels), ${ }^{15}$ and higher equity risk (as captured by lower relative values for owner-occupied housing). In addition, African-Americans are more likely to reside in the central city. ${ }^{16}$

Table 2 presents the mean location attributes by race and by whether a household is an owneroccupant. The first two columns represent the mean attributes for white owners and renters, and the third column represents the difference between white owners and renters. The next three columns display the same information for African-American households. On average, white owner occupants reside in locations with lower rates of integration, and lower rates of poverty. In addition, white owners are less likely to reside in the city as compared to white renters. These results are not replicable for the AfricanAmerican sample. African-American owner occupants reside in locations with higher percent AfricanAmerican, higher equity risk, and lower amenity levels overall as compared to African-American renters. The last column shows the difference between the third and sixth columns. From the last column we can see that the white owner vs. renter differences and African-American owner vs. renter differences are significantly different from each other for all variables except percent poverty. These results illustrate the importance of considering residential location when examining tenure choice and allowing location to be endogenous. African-Americans reside in locations that have higher poverty rates, lower overall quality as measured by price level, and higher equity risk. These factors are likely to influence both the costs and benefits of owner-occupied housing relative to rental housing. Moreover, homeowners tend to reside in 
different types of neighborhoods than renters, and these differences vary systematically by race. This finding suggests that residential location is endogenous to the tenure choice and that ignoring this endogeneity may be very problematic in any analysis of racial differences in homeownership.

\section{ESTIMATION AND SIMULATION RESULTS}

\subsection{Residential Location Choice Model}

Table 3 presents the estimates from the first stage multinomial logit model which analyzes residential location choice conditional on the tenure choice. Note that the first stage estimates the conditional probability of a residential location choice given the tenure choice and that the coefficients for the first stage models are estimable only up to a scale factor. In addition, these estimates should be interpreted with care because they will suffer from selection bias if location choice is endogenous to tenure choice. The estimates from the first stage logit are used to construct an inclusive value representing the relative utility of owning versus renting for each residential location and individual in the sample. The inclusive value will be added to the second stage tenure model, which will provide consistent estimates for describing household tenure choice.

The coefficients are presented in four panels based on the following categories: white owners, African-American owners, white renters, and African-American renters. For each panel, the first column contains the estimated level coefficients for the households described by the omitted categories, i.e., single individuals without a high school degree. The second column contains the difference between the coefficients for single and married households, and the third and fourth columns contain the interaction of coefficients for the reference individual being a high school or college graduate, respectively. The last three columns contain the probability of employment and its interaction with marital status for head of household and spouse, respectively.

The rows contain the location attributes. The first two rows include the controls for aggregation bias, i.e., option size (number of units) and variance of option utility (variation in price). No information is available to capture variation in size or utility based on observed characteristics. Therefore these two 
variables are simply included without interactions. The next five rows include percent households African-American, percent households in poverty, price level conditional on tenure, equity risk, and central city, which are interacted with marital status and education. Finally, the last row contains a gravity-model-based measure of job access, and this measure of job access is interacted with the probability of employment for the reference individual, marital status, and the probability of the reference person's spouse if married.

It is important to remember when interpreting the results in this table that the model includes a control for the amenity level in each zone. This control is based on the location fixed effect from a hedonic price estimation. If a type of household is has the average willingness to pay for these unobserved amenity variables and has free access to the metropolitan housing market, there should be no relationship between price level and the desirability of a location because the cost of the unobserved variables simply equals the value place on them by the household. Moreover, the influence of all other attributes should be interpreted in the context that price level is held constant. For example, if equity risk decreases, the decrease in equity risk must be associated with a change in unobserved amenity variables since price is held constant. In essence, the willingness to pay for other attributes is measured in the willingness to give up quality on the unobserved amenity variables. Moreover, if there are constraints to mobility within the metropolitan area, such as racial discrimination or mortgage redlining, across group location differences may reflect these constraints rather than differences in willingness to pay. This analysis cannot distinguish between across group differences in preferences and such constraints.

For white owners occupants (Panel A), unmarried individuals without a high school education avoid locations with high concentrations of blacks, expensive quality adjusted housing prices, and high equity risk. Other things equal, these individuals will reside in a central city location over a suburban location. On the other hand, married individuals tend to reside in suburban locations. Also, as education level rises, households loose their aversion to locations with high minority concentrations, high price levels and high equity risk. Therefore, households with high education levels are more likely in zones with high amenity levels even after controlling for the higher price levels in those zones. Moreover, high 
education households are more likely to reside in locations with a high concentration of minorities or high equity risk potentially because they are less willing to sacrifice overall amenity levels in order to avoid locations with these attributes. The exact view of these households towards minority neighborhoods or equity risk is obscured by the fact that high education level households appear to place a higher value on amenities. Employment access increases the likelihood of a household residing in a location, but the role of employment access falls with the probability of employment for single individuals, as well as with the spouse's probability of employment for married couples. Individuals with a high probability of employment may be less likely to sacrifice other features of the location in order to have good job access.

For black households (Panel B), the basic findings are the same except for the effect of percent black. Black households are more likely to reside in locations with a high percentage of minorities, and there is some evidence (significant for high school graduates, but not for college graduate) that the effect actually increases with education. Note that the effect of equity risk for non-high school graduates, the central city effects, and the effect of the spouse's probability of employment are not statistically significant. Naturally, these estimates describe location outcomes and can be interpreted as representing preferences only if African Americans have complete and unconstrained access to all locations within the metropolitan area. If African Americans access to housing is constrained by discrimination and geographic steering, these estimates will represent a composite of African American preferences and the effect of external constraints on location choice.

For white renters (Panel C), unmarried, uneducated whites are less likely to reside in locations with high minority concentrations, high poverty percentage, high price levels, but more likely to reside in central city locations and locations with equity risk. In principle, renters should not care about equity risk, but the reversal of the coefficients on the equity risk variables relative to the owner-occupant results appears reasonable because they may prefer to reside in a location with higher equity risk and the higher amenity variables that are implied when price is held constant. As with white and African-American owners, the likelihood of residing in zones with high amenity levels increases with education level. As a result, the effects for percent black and percent poverty are reversed or at least eroded in size as education 
level increases. However, renters develop an aversion to equity risk as education increases, but the increase in the value of unobserved amenity variables should imply an increased willingness for renters to accept locations with equity risk. Possibly, households expect to move within the same location. High education households may foresee owning in the future and choose to avoid high equity risk areas.

Black renters (Panel D) are more likely to live in locations with a high percentage of AfricanAmerican households and less likely to live in locations with equity risk. The standard relationship between education level and the influence of price level occurs for black renters, and there is also a corresponding increase in the likelihood of black renters residing in a location with a high poverty rate. For both black and white renters, employment access appears to make a location more attractive, but as with owners the affect decreases with the probability of unemployment.

\subsection{Tenure Choice Model}

Table 4 contains the estimates from three separate estimations: Model I, a standard model that contains no spatial information; Model II, a model that includes five key exogenous residential location attributes: percent black, percent poverty, price level, equity risk, and central city; and Model III, a nested multinomial logit model $^{17}$ that consider residential location choices endogenously through the inclusive utility variable obtained from the first stage residential location logit estimation. ${ }^{18}$ In general, results across all three specifications support the key findings of previous research on homeownership, namely that being credit constrained lowers the likelihood of owning, a higher household income increases the likelihood of owning, and the effect of facing a downpayment constraint is larger for minorities.

The first two models are potentially biased. The standard model (Model I) omits location and to the extent that location influences tenure choice the model suffers from omitted variable bias. Model II controls for location, but may be biased in that location is endogenous to tenure choice. In comparing Model I to the consistent estimates offered by Model III, we observe almost no change in the white coefficients on credit constraints and family income. The racial interactions, however, do appear to suffer from omitted variable bias. The interaction coefficient on downpayment constraint appears biased upwards by over $10 \%$. The interaction coefficient on family income is biased upwards by $80 \%$ leading to 
a result that is significant at the $10 \%$ level in Model I, but insignificant in Model III. In comparing Model II to Model III, the biases are potentially even more problematic. The biases on the racial interaction are still considerable: approximately $10 \%$ for the constraint variable and $50 \%$ for family income, and the level coefficients also suffer from substantial bias in this specification. The estimated coefficients on both the constraint and family income variables are biased upwards by about $15 \%$. Clearly, the simple inclusion of controls for actual residential location on the right hand side of a tenure choice model is not an appropriate solution in this context.

In Model II, which includes location attributes as exogenous explanatory variables, the amenity/price index, percent black, and equity risk all reduce the likelihood of owning. For the amenity/price index, African-Americans tend to reside in lower quality locations, which should decrease racial differences in homeownership. However, percent black and equity risk only reduce the likelihood of owning for white households. The sum of the white coefficients and the racial interactions are effectively zero for these two variables. For these two variables, interpretation depends on the point of comparison. If the typical location of white households forms the basis for comparison, the fact that African-American households reside in more integrated locations and in locations with higher equity risk has little effect on racial differences in homeownership. Finally, poverty rate in a location lowers the likelihood of homeownership for African-Americans, but not for whites. Again using the residential location of white households in the sample as a baseline, African-American households are exposed to higher poverty rates, which would tend to increase racial differences in homeownership.

One limitation of Model II is that the residential location is considered as an exogenous choice in the tenure choice decision. Presumably, an optimal tenure choice should be made while fully considering the impact of residential location choice, and vise versa. The nested multinomial model provides a coherent framework to analyze household's tenure choice and residential location choice endogenously. The results for the nested multinomial logit provide strong support of the hypothesis that residential location choices are endogenous to the tenure choice. The coefficient on the inclusive value is positive and significantly different from zero which implies location matters in the owner-occupancy decision. It 
is also significantly different from one which implies that the complete choice process cannot be modeled as a simple multinomial logit over all combinations of residential location and homeownership options.

However, a statistically significant coefficient on the inclusive value alone may not lead to a conclusion that residential location options influence racial differences in homeownership. Such a conclusion also requires a comparison of the estimated inclusive values across the white and AfricanAmerican samples. The mean inclusive value for the white sample is -0.556 with a standard error of 0.469 , and the mean for the African-American sample is 2.321 with a standard error of $0.561{ }^{19}$ The difference in inclusive utilities between the white and the African-American samples is 2.877 with a standard error of 0.695 . On average, the set of options available in this metropolitan area increase the likelihood of homeownership among African-American households relative to whites. ${ }^{20}$

A number of alternative specifications were considered for key household characteristics, and partial results are shown in table 5. The constraint variable was constructed either using an alternative discount rate or by using directly estimated coefficients from a model of household assets using the Survey of Consumer Finance. The number of family members with a given relationship to the reference person was used to replace the binary indicator for whether someone of that relationship was present. Years-of-education was used to replace educational attainment. ${ }^{21}$ Finally, family income was replaced with an instrumental variable. The basic results are robust to these alternative specifications. ${ }^{22}$

\subsection{Simulation Results}

In order to assess the magnitude of the effects discussed above, as well as to examine the underlying factors behind these effects, we conduct simulation analyses using the estimated models. First, the base model (model 1) is used to examine the effect of credit constraints on racial differences in homeownership. For the sample, the model predicts a 22 percentage point difference between white and African American homeownership rates. The elimination of credit constraints within the sample drive the racial difference down by 77 percent or down to 5 percentage points. This result is consistent with 
previous findings by Gyouko, Linneman and Wachter (1999) that credit constraints and other endowment differences can explain a very large portion of observed racial differences in homeownership.

For the model in which location is assumed to be exogenous (model 2), the simulations simply examine the effect of altering the residential location attributes experienced by the households in the sample. Table 6 contains simulations based on the model in which residential location is treated as exogenous. As shown in Table 1, African-Americans in this sample reside in locations that contain a higher percentage of African-American households, contain a higher percentage of households in poverty, have lower neighborhood quality as captured by the amenity/price index, have higher equity risk, and more likely to be in the central city. This simulation eliminates these differences by altering the value of these variables for either the white or minority sample so that the mean values of a location attribute are equal for the white and African-American samples.

The two largest effects in Table 6 arise from the modification of percent households in poverty and the amenity/price index. A decrease in the neighborhood poverty faced by African-Americans to the level faced by white households on average lowers predicted racial differences in homeownership. After controlling for the overall amenity level and racial composition, African-Americans are much less likely than white households to own in neighborhoods with high poverty rates. Since the simulation controls for the amenity/price index, the effect of poverty rates is measured relative to the associated decrease in unobserved neighborhood quality that must occur in order to hold prices constant while poverty rates decline. An adjustment to the amenity/price index appears to work in the opposite direction. When African-Americans face the higher prices for housing that are associated with better neighborhood amenities, racial differences in homeownership rates increase. ${ }^{23}$ Table 6 also shows the effect of eliminating average differences for all attributes considered simultaneously. Racial differences in homeownership increase moderately in this simulation.

These results provide mixed evidence of the hypothesis that the residential location of AfricanAmerican households limits their homeownership opportunities. Using white household residential locations as a baseline, the fact that minorities reside in locations with high poverty rate does appear to 
limit homeownership opportunities. However, the overall amenity level associated with a location appears to have the opposite effect in that either the lower prices or lower levels of racial discrimination in poorer quality locations increase minority homeownership. These two effects cancel each out when all attribute differences are eliminated. This simulation shows an increase in racial differences in homeownership suggesting that the overall pattern of residential location appears to mitigate homeownership differences, but the size of the effect is much smaller.

Table 7 examines the effect of location on homeownership using the estimates from the nested multinomial logit model. The inclusive value represents the value placed on homeownership based on the location opportunities available. The mean inclusive values for the white and African-American subsamples are -0.556 and 2.321, respectively, indicating that location outcomes increase African-American homeownership relative to white households. In order to quantify this effect, row 1 contains the simulated probabilities of homeownership when inclusive values are adjusted so that the mean inclusive value is the same for the white and the African-American samples. This adjustment increases racial differences in homeownership by 17.6 percent. In other words, the residential location outcomes of minority households appear to increase their likelihood of homeownership and as a result mitigate racial differences in homeownership.

This finding raises some questions concerning previous findings that credit constraints can explain the majority of racial differences in homeownership. Existing studies do not consider the fact that minorities tend to purchase homes in different types of locations than whites. If we examine the predicted racial differences while African American household locations were determined in a manner similar to white households, racial differences in the sample increase to 39 percentage points. The elimination of credit constraints within the sample decreases racial differences in homeownership to 22 percentage points. Over half of the racial differences remain. By ignoring residential location, these studies attribute too much importance to racial differences in endowments and potentially understate the extent to which race itself limits access to owner-occupied housing. 
In the nested multinomial logit, the racial differences in the inclusive value can arise from two sources: racial differences in the household characteristics that are included in the residential location choice specification, or the variation in location attributes for which the relative value in homeownership varies by race. The location choice model depends on both marital status and educational attainment, and the white and African-American samples differ on these variables. The second row in Table 7 adjusts the inclusive values so that the mean inclusive values are the same by race for each sub-sample, e.g. single and head does not have a high school degree. The basic results are unaffected by this change. Finally, simulations are conducted to examine whether the racial differences in inclusive values can be attributed to racial differences in either marital status or educational attainment in the sample. The last two rows include simulations in which the inclusive value is modified by adjusting the educational attainment and marital status variables in the sample so that the means of these two variables are the same by race. This adjustment does not affect racial differences in homeownership. Therefore, racial differences in educational attainment and marital status cannot explain the results in the first row of this table. There is no evidence that the influence of residential location choice on relative homeownership rates can be explained by differences in educational attainment or marital status.

Rather, racial differences in the pattern of location outcomes appear to be the major factor in mitigating racial differences in homeownership. Table 8 explores the role of location outcomes by examining the affect of possible changes in the location choice set on racial differences in homeownership rates. In these simulations, the location attributes are changed, rather than the characteristics of the white and/or African-American samples. The first four columns examine a ten percent increase in each location attributes. A simple increase in these characteristics does not affect homeownership rates in any substantial way.

The last four columns examine a ten percent reduction in the standard error associated with mean location attributes. Specifically, the value of an attribute in each location is shifted towards the mean value of that attribute across all locations in order to preserve the mean of the attribute but decrease the variation. A reduction in the variation across locations increases racial differences in homeownership for 
every attribute. The effect for percent African-American households, percent in poverty, and the amenity/price index are on the order of 13 to 15 percentage points and increase racial differences by over 60 percent. A reduction in variation in equity risk has a similar effect, but the effect is smaller possibly due to an interaction between equity risk and the high levels of credit constraints among AfricanAmerican households. It is important to note that our analysis examines a single market and does not allow us to compare households making choices in the face of alternative sets of options. Rather, these results are based on differences in outcomes across household types. The parameter estimates from the residential location model predict higher relative benefits from homeownership for African Americans in the types of neighborhoods that are eliminated when the variation in attributes is reduced.

The simulations in table 8 are partial equilibrium in nature. They do not consider the possibility that a metropolitan wide change in one location attribute may influence equilibrium outcomes for a second attribute. While a general equilibrium analysis of this problem is beyond the scope of the paper, one assumption implicit in the partial equilibrium analysis is considered further. The estimations control for the price level of each location through the amenity/price index, and therefore a simulated change in an attribute is conducted holding price level fixed. For example, if a decrease in percent poverty is expected to increase the prices in a given location, these simulations assume that unobserved neighborhood attributes are simultaneously decreased in order to leave the price level unaffected.

The third and sixth rows of table 8 address this concern. Specifically, the relationship between price level and other location attributes was estimated on the sample of zones using the price fixed effects from the housing price hedonic estimation as the dependent variable. ${ }^{24}$ A significant relationship was found for both percent poverty and equity risk. The estimated relationship was used to adjust the price level variable as the percent poverty and equity risk variables were modified. Again in a partial equilibrium framework, simulations with this price level adjustment can be interpreted as the affect of changing one attribute while holding other attributes fixed including unobserved neighborhood quality. The simulations based on this price adjustment yield very similar results to the simulations in which the price level is held constant. 
These simulations suggest that racial and income segregation across the metropolitan area plays an important role in creating the observed effects on homeownership. One possible explanation is that African-American households self-sort into poorer and lower quality neighborhoods in order to gain access to affordable owner-occupied housing. Under this possibility, a decrease in the variation across residential location options increases racial differences in homeownership rates possibly because it limits choice hindering the self-sorting of African-Americans. Alternative interpretations involving racial discrimination and steering, however, are equally plausible. The steering of African American household's into lower quality neighborhoods where housing price is low would have the same effect as self-sorting. A low price level among the restricted housing alternatives may mitigate downpayment and income constraints and lead to higher homeownership rates. In fact, if steering is more severe in the owner-occupied housing market, African-American owners might be concentrated in poor quality locations rather than choosing homeownership based on the low price of housing in those locations. In this case, a decrease in variation across locations limits the ability of real estate agents to steer minority homebuyers towards specific types of neighborhoods.

\section{SUMMARY AND CONCLUSIONS}

This study estimates a tenure choice model using the 1985 Philadelphia sample of the American Housing Survey. The tenure choice is examined while allowing the residential location choice to be endogenous and controlling for the residential opportunities available throughout the metropolitan area. The study supports standard results in the literature. Family income and a prediction that the household faces a downpayment constraint are both significant determinants of homeownership, and the downpayment constraint has an especially large effect on African-Americans households' homeownership decision. Our simulations indicate that racial differences in homeownership are reduced by 17 percentage points or by 77 percent when credit constraints are eliminated.

Using the tenure choice model, the study examines whether racial differences in homeownership are explained in part by the high levels of racial segregation observed in American metropolitan areas 
and/or the concentration of African Americans into areas with high poverty and poor neighborhood amenities. These factors may limit the value of African-American homeownership opportunities, or when faced with the lower prices and potentially lower levels of discrimination associated with these neighborhoods African-Americans may increase homeownership relative to comparable white households in more highly priced and exclusive locations.

The influence of location choice appears to mitigate racial differences in homeownership rates, rather than contribute to these differences. The predicted inclusive value from the nested multinomial logit captures the advantages of homeownership that arise due to the location opportunities available. The average inclusive value for the African-American sample exceeds the value for the white sample, and the elimination of these differences increases racial differences in homeownership rates by 17 percentage points. An important implication of these findings is that previous studies may have overstated the importance of endowment differences. This paper finds that credit constraints can explain 77 percent of racial differences in homeownership using a traditional model, but when homeownership rates are compared while controlling for location, credit constraints explain less than half of the predicted racial differences in homeownership rates.

We also investigated which features of the opportunity set are behind the influence of location outcomes on homeownership differences. A series of simulations were conducted in which the variation in key location attributes was reduced leading to either less racial segregation, less concentration of poverty, and a more even distribution of the overall amenity level or equity risk. In every one of these simulations, the reduction in variation increased racial differences in homeownership rates. While this study only examines outcomes in one metropolitan area and cannot directly estimate the impact of differences in metropolitan structure, these simulations suggest that racial and income segregation across the metropolitan area plays an important role in creating the observed effects on homeownership

The normative aspects of these conclusions are far from clear. These results might be interpreted positively in that residential segregation does not appear to negatively impact the likelihood of homeownership among African Americans. At the same time, the location pattern of African American 
homeowners should be a source of concern for policymakers. At least in this sample, African American homeowners actually reside in lower quality (as measured by price level) and higher equity risk locations than African American renters. Homeownership is an important wealth accumulation mechanism for American households. However this mechanism may be severely limited if African Americans reside in locations where housing is unlikely to appreciate over time. Moreover, homeownership has been advocated as a mechanism for improving the outcomes of minority youths, but the location pattern of African American homeowners may also negatively impact youths through both access to quality schools and peer group effects. 


\section{APPENDIX: ADDITIONAL MODEL SPECIFICATIONS AND ESTIMATION RESULTS}

\section{A1. Tenure Choice Specification and the Downpayment Constraint}

The household tenure choice specification follows standard approaches in the literature. As suggested by Englehart (1994), households may save in order to obtain a down payment, or savings may be depressed if households do not expect to be able to afford to purchase a residence that meets their desires. ${ }^{25}$ As a result, the tenure choice model is part of a simultaneous system involving a household's decision to accumulate wealth and latent housing demand. A constraint variable is constructed based on reduced form estimates of each household's available assets and each household's demand for owneroccupied housing if they did not face a down payment constraint.

A constraint dummy variable is set to one if the family's predicted assets available for home purchase exceed a set fraction of the predicted optimal house value. Unconstrained households are defined as households that had at least twenty percent equity in their home at the time of purchase. Using this sample, house value at the time of purchase is estimated as a function of family characteristics, residential location, and years since the purchase. Predicted optimal house value is based on the resulting parameter estimates and the assumption that the number of years since the purchase equals zero, see Goodman and Kawai (1982) for an earlier example of this approach. Predicted assets must equal 23 percent of predicted optimal house value in order to allow for a 20 percent downpayment, as well as closing costs and possible points.

Predicted assets are the sum of predicted housing equity and predicted liquid assets. Housing equity is estimated as a function of family characteristics while correcting for sample selection into homeownership, which is a function of both family characteristics and residential location. Housing equity is predicted for the entire sample of households using the model parameter estimates, and the predicted equity times the probability of homeownership is used as an instrument for housing wealth. The non-labor income estimation discussed earlier depends on variables that describe sources of nonlabor income. Predicted incomes from liquid assets are based on the estimated non-labor income model under the assumption that the only sources of income are dividends and interest income. Predicted liquid 
assets for the entire sample are the predicted non-labor income from dividends or interest times the probability of having income from dividends or interest divided by an typical dividend rate of 0.03 . Alternative constraint variables are also considered by raising the return rate to 0.05 to represent a traditional money market account and by using the coefficients from an estimated model of household assets from the 1989 Survey of Consumer Finance. ${ }^{26}$

As described earlier, the constraint variable is based on predicted optimal housing demand and predicted housing equity. Housing equity is calculated based on reported house value for homeowners with no mortgage or with a fixed rate mortgage since the AHS contains interest rates, year of the home purchase, and original mortgage amount. Optimal housing demand is estimated using the purchase price of the housing unit for every homeowner who purchased their home with at least a 20 percent down payment. Both the housing demand and home equity specifications include the same family variables as the tenure choice equation.

The results of these estimations are shown in Table A1. These results are simply reduced form estimations and are only used to generate instruments for the estimations reported in the body of the paper. Also, note that predicted values used in later estimations do not depend on residential location. Rather, they are based on the sample average of the estimated location fixed effects.

\section{A2. Instrument for Family Income}

Family labor income may also be endogenous if family members respond to homeownership requirements and opportunities by adjusting labor supply. As a robustness check, an instrument is also developed for family predicted non-labor family income and predicted labor income for each family member. First, an employment equation is estimated for each adult family member where employment depends on individual characteristics, family structure, and residential location fixed effects. For employed family members, labor earnings are estimated as a function of individual characteristics, family structure, and employment location fixed effects, and the estimation is corrected for sample selection bias. Labor earnings are predicted for each family member and weighted by the probability of employment. 
Both the employment and the labor earnings specification includes many individual characteristics including age with separate intercepts and slopes for each of the following age categories: 16-18, 19-22, 23-55, 55-65, and 65 and older. The specifications also depend on the presence of other family members for the reference person and the relationship to the reference person for all other family members. The labor earnings specification controls for sample selection bias using the Heckman two-step approach. The results are shown in Table A2. As discussed above, predicted employment probability and earnings are do not depend on employment or residential location.

Non-labor income is generated by assets that may have been accumulated in order to finance the purchase of a home. As a result, this portion of family income is replaced by the predicted amount from a reduced form model of non-labor income. Non-labor income is estimated as a function of family characteristics including residential location fixed effects, and then predicted for each household at the average of the estimated fixed effects. Non-labor income depends on the standard family characteristics in the homeownership equation plus residential location fixed effects. The estimated coefficients are shown in Table A1.

\section{A3. Amenity/Price Indices and a Measure of Equity Risk}

Amenity/price indices are constructed for each location and tenure choice by estimating separate hedonic models of housing price for owners and monthly rent for renters using a log-log specification. First, a reduced form housing tenure choice model is estimated depending on family characteristics and residential location. The estimates from the reduced form tenure choice model are used to calculate sample selection terms for the hedonic models. The hedonic models include the physical characteristics of the owner occupied or rental property, as well as residential location fixed effects.

$$
p_{i t}=\gamma X_{i t}+\delta_{j t}+\sigma_{t} \lambda_{i}+\varepsilon_{i t}
$$

where the $\delta$ 's are the location fixed effects, $\lambda$ is the inverse mills ratio from the sample selection correction, and $\varepsilon$ is an error term. The amenity/price index in a given location and tenure is the appropriate fixed effect from the housing price or the rent models. ${ }^{27}$ 
The estimated fixed effects are included directly in the residential location (tenure choice) model as a measure of relative housing costs across locations (tenure). These measures provide controls for the overall amenity level in a location because other things equal these attributes should be capitalized into the price of both owner-occupied and rental housing. In addition, the rental and sales price indices are used to construct a measure of equity risk. Equity risk should lower the value of owner-occupied housing relative to rents on similar properties. Equity risk in any location is estimated as the exponential of the rental fixed effect divided by the exponential of the sales fixed effect. Tootell (1996) uses a similar measure of equity risk, median rents divided by median house value, but Tootell's measure does not control for differences in the quality of rental and owner-occupied housing stock in each location.

The specification of the reduced form tenure choice equation includes the same family characteristics as the final tenure choice equation. Both hedonic specifications include number of square feet, number of each type of room, ages, whether unit contains specific features like a garage, porch or fireplace, type of unit, and if a rental property whether utilities are included in the rent (See Table A3 for details).

\section{A4. A Measure of Job Accessibility}

The residential location choice model also controls for the location to employment offered by each residential location. A gravity model is estimated using the following specification

$$
\log \left[F_{j k}\right]=\alpha_{0}+\alpha_{P} \log \left[P_{j}\right]+\alpha_{E} \log \left[E_{k}\right]+\alpha_{t} \log \left[t_{j k}\right]+\mu_{j k}
$$

where F represents commuting flows, P represents population in location j, E represents employment in location $\mathrm{k}$, $\mathrm{t}$ is the commuting time between $\mathrm{j}$ and $\mathrm{k}$, and $\mu$ is an error term. The measure of job access for a given location is

$$
A_{j}=\sum_{k} E_{k}^{\alpha_{E}} / t^{\alpha_{t}}
$$

which may be included in the residential location choice problem as a location attribute.

The 1990 Census Transportation Planning Package (CTPP) is used to estimate the gravity model for the AHS sample zones in the Philadelphia metropolitan area. The number of automobile commuters 
from one zone to another forms the dependent variable of the model, and the independent variables include number of households in the residential zone, number of jobs in the employment zone, and average peak commute time by automobile between the two zones. The estimated coefficients and standard errors are $-4.210(0.727), 0.959(0.046), 0.954(0.055)$ and $-2.789(0.099)$ for the intercept, number of households, number of jobs, and commute time, respectively. ${ }^{28}$ 


\section{Acknowledgements}

The authors would like to acknowledge the helpful comments of Ed Glaeser, Alan Goodman and Don Haurin; attendees of the AREUEA session on Homeownership at the 1999 ASSA meetings and the AEA session on Race and Urban Poverty at the 2000 ASSA meetings, as well as seminar and workshop participants at Harvard University, Ohio State University, the University of Kansas, the University of Connecticut, and Washington University. This research was made possible by generous financial support from the Lusk Center for Real Estate, Center for Real Estate and Urban Economic Studies, and the Wharton Real Estate Center at the Universities of Southern California, Connecticut and Pennsylvania, respectively. 


\section{References}

Amemiya, T., 1980. Selection of Regressors. International Economic Review 21, 331-353.

Anas, A., 1981. The estimation of multinomial logit models of joint location and travel model choice from aggregated data. Journal of Regional Science 21, 223-242.

Anas, A., Chu, C., 1984. Discrete choice models and the housing price and travel to work elasticities of location demand. Journal of Urban Economics 15, 107-123.

Artle, R., Varaiya, R., 1978. Life cycle consumption and homeownership. Journal of Economic Theory $18,35-58$.

Avery, R.B., Beeson, P.E., Sniderman, M.S. 1996. Accounting for racial differences in housing credit markets. In: Goering, J., Wienk, R. (Eds.), Mortgage Lending, Racial Discrimination, and Federal Policy, Urban Institute Press, Washington D.C.

Ben-Akiva, M., Lerman S., 1985. Discrete Choice Analysis: Theory and Application to Predict Travel Demand, MIT Press, Cambridge, MA.

Boehm, T.P., Ihlanfeldt, K.R., 1991. The revelation of neighborhood preferences: An N-chotomous multivariate probit approach. Journal of Housing Research 1, 33-59.

Borsch-Supan, A., 1987. Econometric Analysis of Discrete Choice. Springer-Verlag, New York, NY.

Brueckner, J.K., 1986. The downpayment constraint and housing tenure choice. Regional Science and Urban Economics 16, 519-525.

Chambers, D.N., 1992. The racial housing price differential and racially transitional neighborhoods. Journal of Urban Economics 32, 214-232.

Coulson, E., 1999. Why are Hispanic and Asian-American homeownership rates so low?: Immigration and other factors. Journal of Urban Economics 45, 209-227.

Cutler, D.M., Glaeser E.L., Vigdor, J.L. 1999. The rise and decline of the American ghetto. Journal of Political Economy 107, 455-506.

DeRango, Kelly, The effect of inter-racial economic inequality of racial segregation: re-examined, unpublished manuscript (1999). 
Duca, J., Rosenthal, S. 1994. Borrowing constraints and access to owner-occupied housing, Regional Science and Urban Economics 24, 301-322.

Englehart, G.V., 1994. House prices and the decision to save for down payments. Journal of Urban Economics 36, 209-237.

Follain, J.R., Jiminez, E., 1985. Estimating the demand for housing characteristics. Regional Science and Urban Economics 15, 77-107.

Gabriel, S., Rosenthal, S.S. 1989. Household location and race: Estimates of a multinomial logit model. Review of Economics and Statistics 71, 240-249.

Goodman, A.C. 1978. Hedonic Prices, Price Indices, and Housing Markets. Journal of Urban Economics $5,471-484$.

Goodman, A.C., Kawai, M., 1982. Permanent income, hedonic prices, and demand for housing: New evidence. Journal of Urban Economics 12, 214-37.

Gyourko, J., Linneman, P., Wachter, S.M., 1999. Analyzing the relation among race, wealth, and homeownership in America. Journal of Housing Economics 8, 63-89.

Gyourko, J., Linneman, P., Wachter, S.M., 1997. Tenure choice and intraurban location: The roles of race and wealth. Wharton Real Estate Center Working Paper.

Haurin, D.R., Hendershott, P.H., Wachter, S.M. 1996. Wealth accumulation and housing choice of young households: An exploratory investigation, Journal of Housing Research 7, 33-57.

Haurin, D.R., Hendershott, P.H. Wachter, S.M. 1997. Borrowing constraints and the tenure choice of young households. Journal of Housing Research 8, 137-54.

Hendershott, P.H., LaFayette, W.C., Haurin, D.R., 1997. Debt usage and mortgage choice: The FHAconventional decision. Journal of Urban Economics 41, 202-217.

Ihanlanfeldt, K., Scafidi, B., In Press. An empirical analysis of racial segregation in four metropolitan areas. Journal of Urban Economics.

Kain, J., Quigley, J., 1972. Housing market discrimination, homeownership, and savings behavior. American Economic Review. 62, 263-77. 
Kain, J., 1992. The spatial mismatch hypothesis: Three decades later. Housing Policy Debate 3, 371460.

Kain, J. 1976. Race, ethnicity, and residential location. In: Grieson, R.E. (Ed.), Urban Economics: Essays in Honor of William S. Vickrey, Lexington Books, Lexington, MA.

Kiel, K.A., Zabel, J.E. 1996. Housing price differentials in U.S. cities: Household and neighborhood racial effects. Journal of Housing Economics 5, 143-165.

Lerman, S.R., 1977. Location, Housing and Automobile Ownership and Model Choice to Work. Transportation Research 14B, 610, 6-11.

Linneman, P., Wachter, S. 1989. The impacts of borrowing constraints on homeownership. AREUEA Journal 17, 389-402.

McFadden, D., 1978. Modelling the Choice of Residential Location. In: Karquist, A. et. al. (Eds.), Spatial Interaction Theory and Planning Models, North-Holland Publishing Company, Amsterdam.

Massey, D., Denton, N., 1993. American Apartheid: Segregation and the Making of the Underclass, Harvard University Press, Cambridge, MA.

Munnell, A.H., Tootell, G.M.B., Browne, L.E. and McEneaney, J., 1996. Mortgage lending in Boston: Interpreting HMDA data. American Economic Review 86, 25-53.

Quigley, J., 1985. Consumer choice of dwelling, neighborhood, and public services. Regional Science and Urban Economics 15, 41-63.

Quigley, J., 1976. Housing demand in the short-run: An analysis of polytomous choice. Explorations in Economic Research 3, 76-102.

O'Regan, K., Quigley, J., 1998. Where youth live: Economic effects of urban space on employment prospects. Urban Studies 35, 1187-1205.

Painter, G., Gabriel, S., Meyers, D., 2001a. Race, immigrant status, and housing tenure choice. Journal of Urban Economics 49, 150-167. 
Painter, G., Gabriel, S. and Meyers, D., 2001b. Paths to homeownership: An analysis of the residential location and homeownership choices of Black households in Los Angeles. Research Institute for Housing American working paper No. 01-03.

Ross, S.L., Tootell, G.M.B., 1999. Redlining, the Community Reinvestment Act, and Private Mortgage Insurance. Center for Real Estate and Urban Economics Studies Working paper, University of Connecticut.

Tootell, G.M.B., 1996. Redlining in Boston: Do Lenders Discriminate against Neighborhoods. Quarterly Journal of Economics 111, 1049-1079.

Train, K., 1986. Qualitative Choice Analysis. The MIT Press, Cambridge, MA.

Turner, M.A., Mickelsons, M., 1992. Patterns of Racial Steering in Four Metropolitan Areas. Journal of Housing Economics 2, 199-234.

Wachter, S.M., Megbolugbe, I.F. 1992. Racial and ethnic disparities in homeownership. Housing Policy Debate 3, 2, 353-370.

Waddell, P.A. 1992. Multinomial logit model of race and urban structure. Urban Geography 13, 12-141. Yinger, J., 1995. Closed doors, opportunities lost: The Continuing Cost of Housing Discrimination. Russell Sage Foundation, New York, NY.

Zorn, P., 1989. Mobility-tenure decisions and financial credit: Do mortgage qualification requirements constrain homeownership? AREUEA Journal. 17, 1-16. 
Table 1. Variable Definitions and Means by Race

\begin{tabular}{l|l|r|r}
\hline Name & Definition & White & Black \\
\hline TENURE & Variable is one is resides in owner-occupied residence & 0.619 & 0.439 \\
AGE & Age in years, average of head and spouse if married & 48.02 & 45.257 \\
MAR & Variable is one if reference person married & 0.565 & 0.310 \\
SEX & Variable is one if reference person is male & 0.693 & 0.462 \\
COLGRAD & Variable is one if ref per and spouse are collage graduate & 0.243 & 0.107 \\
HSGRAD & Variable is one if high school graduate & 0.547 & 0.546 \\
REFPRNT & One if a parent resides with reference person & 0.009 & 0.016 \\
REFCHLD & One if children reside with reference person & 0.458 & 0.545 \\
KIDSLT6 & One if kids less than six are present in household & 0.149 & 0.207 \\
CONST & Variable is one if predict credit constrained & 0.078 & 0.517 \\
LOGINC & Logarithm of total family income & 10.338 & 9.335 \\
PCTBLCK & Percent African American households in residential zone & 0.127 & 0.515 \\
PCTPVTY & Percent households in poverty in residential zone & 0.082 & 0.214 \\
AMNTY/PRC & Zone fixed effect from the housing price hedonic & 8.601 & 8.211 \\
EQTYRSK & Measure of equity risk in zone & 0.304 & 0.371 \\
CENCTY & Variable is one if household resides in central city & 0.287 & 0.737 \\
\hline Sample Size & & 4009 & 956 \\
\hline
\end{tabular}


Table 2. Location Attributes by Race and Owner-Occupancy

\begin{tabular}{|c|c|c|c|c|c|c|c|}
\hline Name $^{1}$ & $\begin{array}{l}\text { White } \\
\text { Owner }\end{array}$ & $\begin{array}{l}\text { White } \\
\text { Renter }\end{array}$ & $\begin{array}{l}\text { White } \\
\text { Owner vs. } \\
\text { Renter }\end{array}$ & $\begin{array}{l}\text { Black } \\
\text { Owner }\end{array}$ & $\begin{array}{l}\text { Black } \\
\text { Renter }\end{array}$ & $\begin{array}{l}\text { Black } \\
\text { Owner vs. } \\
\text { Renter }\end{array}$ & $\begin{array}{l}\text { Difference between } \\
\text { White Own vs. Rent } \\
\text { \& Black Own vs. Rent }\end{array}$ \\
\hline PCTBLCK & $\begin{array}{c}0.115 \\
(0.003)\end{array}$ & $\begin{array}{c}0.145 \\
(0.005)\end{array}$ & $\begin{array}{c}-0.030 \\
(0.006)\end{array}$ & $\begin{array}{c}0.551 \\
(0.014)\end{array}$ & $\begin{array}{c}0.488 \\
(0.012)\end{array}$ & $\begin{array}{c}0.063 \\
(0.018)\end{array}$ & $\begin{array}{c}-0.093 \\
(0.019)\end{array}$ \\
\hline PCTPVTY & $\begin{array}{c}0.079 \\
(0.001)\end{array}$ & $\begin{array}{c}0.088 \\
(0.002)\end{array}$ & $\begin{array}{c}-0.009 \\
(0.002)\end{array}$ & $\begin{array}{c}0.210 \\
(0.006)\end{array}$ & $\begin{array}{c}0.217 \\
(0.005)\end{array}$ & $\begin{array}{c}-0.007 \\
(0.008)\end{array}$ & $\begin{array}{l}-0.002 \\
(0.008)\end{array}$ \\
\hline AMNTY/PRC & $\begin{array}{c}8.601 \\
(0.004)\end{array}$ & $\begin{array}{c}8.602 \\
(0.006)\end{array}$ & $\begin{array}{c}-0.001 \\
(0.007)\end{array}$ & $\begin{array}{c}8.178 \\
(0.018)\end{array}$ & $\begin{array}{c}8.237 \\
(0.019)\end{array}$ & $\begin{array}{l}-0.059 \\
(0.026)\end{array}$ & $\begin{array}{c}-0.060 \\
(0.027)\end{array}$ \\
\hline EQTYRSK & $\begin{array}{c}0.303 \\
(0.001)\end{array}$ & $\begin{array}{c}0.304 \\
(0.001)\end{array}$ & $\begin{array}{c}-0.001 \\
(0.001)\end{array}$ & $\begin{array}{c}0.383 \\
(0.003)\end{array}$ & $\begin{array}{c}0.361 \\
(0.003)\end{array}$ & $\begin{array}{c}0.022 \\
(0.005)\end{array}$ & $\begin{array}{c}-0.023 \\
(0.005)\end{array}$ \\
\hline CENCTY & $\begin{array}{c}0.261 \\
(0.009)\end{array}$ & $\begin{array}{c}0.328 \\
(0.012)\end{array}$ & $\begin{array}{l}-0.067 \\
(0.015)\end{array}$ & $\begin{array}{c}0.740 \\
(0.021)\end{array}$ & $\begin{array}{c}0.735 \\
(0.019)\end{array}$ & $\begin{array}{c}0.005 \\
(0.029)\end{array}$ & $\begin{array}{r}-0.072 \\
(0.033)\end{array}$ \\
\hline Sample Size & 2483 & 1526 & & 420 & 536 & & \\
\hline
\end{tabular}

1. The standard errors of the sample mean and differences of means are listed in parentheses. 
Table 3: Residential Location Parameters ${ }^{1}$

Panel A: White Owner-Occupants

\begin{tabular}{l|c|c|c|c|c|c|c}
\hline Variable Name & Level & Married & $\begin{array}{c}\text { High } \\
\text { School }\end{array}$ & College & $\begin{array}{c}\text { Prob. } \\
\text { Employed }\end{array}$ & $\begin{array}{c}\text { Married } \\
\text { Pr. Emp } \\
\text { Head }\end{array}$ & $\begin{array}{c}\text { Married } \\
\text { Pr. Emp } \\
\text { Spouse }\end{array}$ \\
\hline Size of Option & 0.164 & & & & & & \\
Option Variance & 0.022 & & & & & & \\
Percent Black & $(0.219)$ & -1.974 & -0.387 & 1.025 & 2.772 & & \\
Percent Poverty & $(3.782)$ & $(0.847)$ & $(1.797)$ & $(3.981)$ & & & \\
Amenity/Price & -2.264 & -1.487 & -1.187 & 0.058 & & & \\
Equity Risk & $(1.062)$ & $(0.682)$ & $(0.612)$ & $(0.023)$ & & & \\
Central City & -2.687 & -0.047 & 2.167 & 6.424 & & & \\
& $(4.842)$ & $(0.097)$ & $(4.065)$ & $(10.206)$ & & & \\
Employment & -10.706 & 1.168 & 8.488 & 1.649 & & & \\
Access & $(5.131)$ & $(0.638)$ & $(4.117)$ & $(6.637)$ & & & \\
\hline
\end{tabular}

Panel B: Black Owner-Occupants

\begin{tabular}{l|c|c|c|c|c|c|c}
\hline Variable Name & Level & Married & $\begin{array}{c}\text { High } \\
\text { School }\end{array}$ & College & $\begin{array}{c}\text { Prob. } \\
\text { Employed }\end{array}$ & $\begin{array}{c}\text { Married } \\
\text { Pr. Emp } \\
\text { Head }\end{array}$ & $\begin{array}{c}\text { Married } \\
\text { Pr. Emp } \\
\text { Spouse }\end{array}$ \\
\hline Size of Option & 0.231 & & & & & & \\
Option Variance & 0.379 & & & & & & \\
Percent Black & $(1.148)$ & & & & & & \\
Percent Poverty & $(5.111$ & 0.014 & 1.552 & 1.800 & & & \\
& -1.912 & $(0.021)$ & $(2.249)$ & $(1.619)$ & & & \\
Amenity/Price & $(0.865)$ & $(1.560)$ & $(0.646)$ & $(1.110)$ & & & \\
Equity Risk & -1.770 & -0.393 & 2.531 & 1.624 & & & \\
Central City & $(1.938)$ & $(0.592)$ & $(2.184)$ & $(0.690)$ & & & \\
& -4.495 & 0.977 & 9.964 & 12.413 & & & \\
Employment & $(1.598)$ & $(0.542)$ & $(3.077)$ & $(2.261)$ & & & \\
Access & 0.505 & -0.683 & -0.537 & -0.778 & & & \\
\hline
\end{tabular}


Table 3: Residential Location Parameters (Continued)

Panel C: White Renters

\begin{tabular}{l|c|c|c|c|c|c|c|}
\hline Variable Name & Level & Married & $\begin{array}{c}\text { High } \\
\text { School }\end{array}$ & College & $\begin{array}{c}\text { Prob. } \\
\text { Employed }\end{array}$ & $\begin{array}{c}\text { Married } \\
\text { Pr. Emp } \\
\text { Head }\end{array}$ & $\begin{array}{c}\text { Married } \\
\text { Pr. Emp } \\
\text { Spouse }\end{array}$ \\
\hline Size of Option & 0.743 & & & & & & \\
Option Variance & -0.644 & & & & & & \\
Percent Black & $(1.179)$ & -1.579 & -2.396 & 1.052 & 2.077 & & \\
Percent Poverty & $(2.860)$ & $(3.778)$ & $(1.685)$ & $(2.867)$ & & & \\
& -8.182 & 1.321 & 0.945 & 5.260 & & & \\
Amenity/Price & $(4.036)$ & $(0.588)$ & $(0.512)$ & $(2.384)$ & & & \\
& -3.394 & 0.012 & 2.692 & 5.878 & & & \\
Equity Risk & $(5.737)$ & $(0.022)$ & $(4.821)$ & $(8.541)$ & & & \\
Central City & 3.964 & 5.385 & -4.380 & -6.685 & & & \\
& $(2.544)$ & $(3.313)$ & $(2.501)$ & $(3.328)$ & & & \\
Employment & 0.372 & -0.196 & -0.232 & 0.377 & & & \\
Access & $(2.280)$ & $(1.061)$ & $(1.186)$ & $(1.625)$ & & & \\
\hline
\end{tabular}

Panel D: Black Renters

\begin{tabular}{|c|c|c|c|c|c|c|c|}
\hline Variable Name & Level & Married & $\begin{array}{l}\text { High } \\
\text { School }\end{array}$ & College & $\begin{array}{l}\text { Prob. } \\
\text { Employed }\end{array}$ & $\begin{array}{c}\text { Married } \\
\text { Pr. Emp } \\
\text { Head }\end{array}$ & $\begin{array}{l}\text { Married } \\
\text { Pr. Emp } \\
\text { Spouse }\end{array}$ \\
\hline Size of Option & $\begin{array}{r}0.338 \\
(3.774)\end{array}$ & & & & & & \\
\hline Option Variance & $\begin{array}{c}1.410 \\
(1.314)\end{array}$ & & & & & & \\
\hline Percent Black & $\begin{array}{r}2.569 \\
(5.137)\end{array}$ & $\begin{array}{l}-0.315 \\
(0.492)\end{array}$ & $\begin{array}{c}0.821 \\
(1.321)\end{array}$ & $\begin{array}{c}0.208 \\
(0.210)\end{array}$ & & & \\
\hline Percent Poverty & $\begin{array}{c}0.099 \\
(0.034)\end{array}$ & $\begin{array}{l}-0.828 \\
(0.180)\end{array}$ & $\begin{array}{r}4.898 \\
(1.750)\end{array}$ & $\begin{array}{l}11.752 \\
(2.572)\end{array}$ & & & \\
\hline Amenity/Price & $\begin{array}{l}-1.724 \\
(1.536)\end{array}$ & $\begin{array}{l}-1.148 \\
(0.747)\end{array}$ & $\begin{array}{r}3.325 \\
(2.926)\end{array}$ & $\begin{array}{r}8.820 \\
(4.790)\end{array}$ & & & \\
\hline Equity Risk & $\begin{array}{r}-4.648 \\
(3.400)\end{array}$ & $\begin{array}{l}-1.828 \\
(1.319)\end{array}$ & $\begin{array}{c}2.511 \\
(1.383)\end{array}$ & $\begin{array}{l}-0.176 \\
(0.063)\end{array}$ & & & \\
\hline Central City & $\begin{array}{c}0.396 \\
(1.453)\end{array}$ & $\begin{array}{c}0.105 \\
(0.278)\end{array}$ & $\begin{array}{c}-0.626 \\
(1.771)\end{array}$ & $\begin{array}{l}-0.111 \\
(0.191)\end{array}$ & & & \\
\hline $\begin{array}{l}\text { Employment } \\
\text { Access }\end{array}$ & $\begin{array}{c}7.528 \\
(5.087)\end{array}$ & $\begin{array}{l}-2.878 \\
(0.763)\end{array}$ & & & $\begin{array}{l}-13.913 \\
(6.985)\end{array}$ & $\begin{array}{c}20.706 \\
(1.905)\end{array}$ & $\begin{array}{l}-30.718 \\
(2.306)\end{array}$ \\
\hline
\end{tabular}

1. T-Statistics are shown in parentheses. The estimates in all panels were obtained from one pooled model. The pooled likelihood value is $-16,142$. 
Table 4: Tenure Choice Models Using Baseline Specification

\begin{tabular}{|c|c|c|c|c|c|c|}
\hline \multirow[t]{2}{*}{ Variable Names } & \multicolumn{2}{|c|}{ Standard } & \multicolumn{2}{|c|}{ Location Attributes } & \multicolumn{2}{|c|}{ Nested Logit Model $^{1}$} \\
\hline & White & Race Int. & White & Race Int. & White & Race Int. \\
\hline Intercept & $\begin{array}{c}-7.796 \\
(11.299)\end{array}$ & $\begin{array}{c}1.471 \\
(0.907)\end{array}$ & $\begin{array}{c}8.212 \\
(2.275)\end{array}$ & $\begin{array}{l}-12.110 \\
(1.082)\end{array}$ & $\begin{array}{c}-6.614 \\
(7.718)\end{array}$ & $\begin{array}{c}0.973 \\
(0.596)\end{array}$ \\
\hline $\begin{array}{l}\text { Credit } \\
\text { Constrained }\end{array}$ & $\begin{array}{c}-0.678 \\
(3.568)\end{array}$ & $\begin{array}{l}-0.687 \\
(2.345)\end{array}$ & $\begin{array}{l}-0.755 \\
(3.912)\end{array}$ & $\begin{array}{l}-0.674 \\
(2.232)\end{array}$ & $\begin{array}{l}-0.666 \\
(3.505)\end{array}$ & $\begin{array}{l}-0.611 \\
(2.071)\end{array}$ \\
\hline $\begin{array}{l}\text { Household } \\
\text { Income }\end{array}$ & $\begin{array}{c}0.306 \\
(6.354)\end{array}$ & $\begin{array}{c}0.220 \\
(1.760)\end{array}$ & $\begin{array}{c}0.345 \\
(6.886)\end{array}$ & $\begin{array}{c}0.182 \\
(1.379)\end{array}$ & $\begin{array}{c}0.305 \\
(6.341)\end{array}$ & $\begin{array}{c}0.124 \\
(0.969)\end{array}$ \\
\hline $\begin{array}{l}\text { Gender of } \\
\text { Householder }\end{array}$ & $\begin{array}{c}0.292 \\
(2.631)\end{array}$ & $\begin{array}{c}-0.339 \\
(1.424)\end{array}$ & $\begin{array}{c}0.271 \\
(2.420)\end{array}$ & $\begin{array}{l}-0.256 \\
(1.053)\end{array}$ & $\begin{array}{c}0.281 \\
(2.509)\end{array}$ & $\begin{array}{l}-0.397 \\
(1.661)\end{array}$ \\
\hline Marital Status & $\begin{array}{l}-2.404 \\
(3.082)\end{array}$ & $\begin{array}{c}0.838 \\
(0.413)\end{array}$ & $\begin{array}{l}-2.586 \\
(3.290)\end{array}$ & $\begin{array}{c}0.517 \\
(0.248)\end{array}$ & $\begin{array}{l}-2.044 \\
(2.568)\end{array}$ & $\begin{array}{l}-0.311 \\
(0.147)\end{array}$ \\
\hline $\begin{array}{l}\text { High School } \\
\text { Graduate }\end{array}$ & $\begin{array}{l}-0.364 \\
(2.657)\end{array}$ & $\begin{array}{c}0.538 \\
(2.002)\end{array}$ & $\begin{array}{l}-0.244 \\
(1.755)\end{array}$ & $\begin{array}{c}0.257 \\
(0.921)\end{array}$ & $\begin{array}{l}-1.640 \\
(2.898)\end{array}$ & $\begin{array}{c}0.805 \\
(2.729)\end{array}$ \\
\hline College Graduate & $\begin{array}{c}-0.219 \\
(1.251)\end{array}$ & $\begin{array}{l}-0.070 \\
(0.166)\end{array}$ & $\begin{array}{l}-0.021 \\
(0.115)\end{array}$ & $\begin{array}{c}-0.282 \\
(0.648)\end{array}$ & $\begin{array}{l}-2.454 \\
(2.509)\end{array}$ & $\begin{array}{l}1.310 \\
(1.799)\end{array}$ \\
\hline $\begin{array}{l}\text { Married*High } \\
\text { School }\end{array}$ & $\begin{array}{c}1.180 \\
(4.996)\end{array}$ & $\begin{array}{l}-0.497 \\
(0.807)\end{array}$ & $\begin{array}{c}1.194 \\
(5.023)\end{array}$ & $\begin{array}{l}-0.312 \\
(0.494)\end{array}$ & $\begin{array}{c}1.211 \\
(5.110)\end{array}$ & $\begin{array}{l}-0.426 \\
(0.694)\end{array}$ \\
\hline Married *College & $\begin{array}{c}1.103 \\
(4.010)\end{array}$ & $\begin{array}{l}-0.699 \\
(0.904)\end{array}$ & $\begin{array}{c}1.148 \\
(4.144)\end{array}$ & $\begin{array}{l}-0.482 \\
(0.605)\end{array}$ & $\begin{array}{c}1.075 \\
(3.909)\end{array}$ & $\begin{array}{l}-0.711 \\
(0.926)\end{array}$ \\
\hline $\begin{array}{l}\text { Parents Present in } \\
\text { Household }\end{array}$ & $\begin{array}{c}0.775 \\
(1.765)\end{array}$ & $\begin{array}{c}0.454 \\
(0.575)\end{array}$ & $\begin{array}{c}0.820 \\
(1.876)\end{array}$ & $\begin{array}{c}0.623 \\
(0.791)\end{array}$ & $\begin{array}{c}0.780 \\
(1.773)\end{array}$ & $\begin{array}{c}0.514 \\
(0.642)\end{array}$ \\
\hline $\begin{array}{l}\text { Children Present } \\
\text { in Household }\end{array}$ & $\begin{array}{c}0.734 \\
(7.058)\end{array}$ & $\begin{array}{l}-0.175 \\
(0.795)\end{array}$ & $\begin{array}{c}0.725 \\
(6.905)\end{array}$ & $\begin{array}{l}-0.140 \\
(0.617)\end{array}$ & $\begin{array}{c}0.734 \\
(7.058)\end{array}$ & $\begin{array}{l}-0.102 \\
(0.457)\end{array}$ \\
\hline $\begin{array}{l}\text { Children Less } \\
\text { than } 6 \text { Years Old }\end{array}$ & $\begin{array}{c}0.442 \\
(3.007)\end{array}$ & $\begin{array}{l}-0.429 \\
(1.560)\end{array}$ & $\begin{array}{c}0.423 \\
(2.858)\end{array}$ & $\begin{array}{l}-0.440 \\
(1.571)\end{array}$ & $\begin{array}{c}0.426 \\
(2.898)\end{array}$ & $\begin{array}{l}-0.275 \\
(0.965)\end{array}$ \\
\hline $\begin{array}{l}\text { Age of } \\
\text { Householder }\end{array}$ & $\begin{array}{c}0.147 \\
(7.462)\end{array}$ & $\begin{array}{l}-0.122 \\
(2.837)\end{array}$ & $\begin{array}{c}0.141 \\
(7.085)\end{array}$ & $\begin{array}{l}-0.129 \\
(2.867)\end{array}$ & $\begin{array}{c}0.146 \\
(7.411)\end{array}$ & $\begin{array}{l}-0.133 \\
(3.043)\end{array}$ \\
\hline $\begin{array}{l}\text { Age Squared } \\
\text { Divided by } 100\end{array}$ & $\begin{array}{c}-0.104 \\
(5.876)\end{array}$ & $\begin{array}{c}0.107 \\
(2.629)\end{array}$ & $\begin{array}{l}-0.098 \\
(5.511)\end{array}$ & $\begin{array}{c}0.114 \\
(2.682)\end{array}$ & $\begin{array}{l}-0.102 \\
(5.763)\end{array}$ & $\begin{array}{c}0.130 \\
(3.088)\end{array}$ \\
\hline Married*Age & $\begin{array}{c}0.120 \\
(3.859)\end{array}$ & $\begin{array}{l}-0.075 \\
(0.889)\end{array}$ & $\begin{array}{c}0.126 \\
(4.026)\end{array}$ & $\begin{array}{l}-0.064 \\
(0.736)\end{array}$ & $\begin{array}{c}0.126 \\
(4.038)\end{array}$ & $\begin{array}{l}-0.052 \\
(0.606)\end{array}$ \\
\hline $\begin{array}{l}\text { Married *Age } \\
\text { Squared }\end{array}$ & $\begin{array}{l}-0.116 \\
(3.867)\end{array}$ & $\begin{array}{c}0.104 \\
(1.211)\end{array}$ & $\begin{array}{l}-0.120 \\
(3.974)\end{array}$ & $\begin{array}{c}0.091 \\
(1.022)\end{array}$ & $\begin{array}{l}-0.128 \\
(4.224)\end{array}$ & $\begin{array}{c}0.079 \\
(0.912)\end{array}$ \\
\hline
\end{tabular}


Table 4: Tenure Choice Models Using Baseline Specification (Continued)

\begin{tabular}{|c|c|c|c|c|c|c|}
\hline \multirow[t]{2}{*}{ Variable Names } & \multicolumn{2}{|c|}{ Standard } & \multicolumn{2}{|c|}{ Location Attributes } & \multicolumn{2}{|c|}{ Nested Logit Model } \\
\hline & White & Race Int. & White & Race Int. & White & Race Int. \\
\hline $\begin{array}{l}\text { Percent Black in } \\
\text { Zone }\end{array}$ & & & $\begin{array}{l}-1.069 \\
(2.527)\end{array}$ & $\begin{array}{c}1.656 \\
(2.346)\end{array}$ & & \\
\hline $\begin{array}{l}\text { Percent Poverty } \\
\text { in Zone }\end{array}$ & & & $\begin{array}{c}0.701 \\
(0.499)\end{array}$ & $\begin{array}{l}-10.261 \\
(3.464)\end{array}$ & & \\
\hline $\begin{array}{l}\text { Amenity/Price } \\
\text { Index in Zone }\end{array}$ & & & $\begin{array}{l}-1.782 \\
(4.778)\end{array}$ & $\begin{array}{l}-1.257 \\
(1.060)\end{array}$ & & \\
\hline $\begin{array}{l}\text { Equity Risk in } \\
\text { Zone }\end{array}$ & & & $\begin{array}{l}-3.123 \\
(2.065)\end{array}$ & $\begin{array}{c}3.563 \\
(1.128)\end{array}$ & & \\
\hline $\begin{array}{l}\text { Central City } \\
\text { Location }\end{array}$ & & & $\begin{array}{l}-0.083 \\
(0.664)\end{array}$ & $\begin{array}{c}0.372 \\
(1.107)\end{array}$ & & \\
\hline Inclusive Value & & & & & $\begin{array}{c}0.346 \\
(2.322)\end{array}$ & \\
\hline Log likelihood & \multicolumn{2}{|c|}{$-2,448.38$} & \multicolumn{2}{|c|}{$-2,402.79$} & \multicolumn{2}{|c|}{$-2,445.66$} \\
\hline
\end{tabular}

1. T-Statistics are based on standard errors have been generated through a Monte Carlo simulation approach. 
Table 5: Tenure Choice Models - Alternative Specifications

\begin{tabular}{|c|c|c|c|c|c|c|}
\hline Variable Names ${ }^{1}$ & Baseline & $\begin{array}{l}\text { Alt Constraint - } \\
5 \% \text { disc rate }\end{array}$ & $\begin{array}{l}\text { Alt Constraint - } \\
\text { SCF }\end{array}$ & $\begin{array}{l}\text { Instrument for } \\
\text { Family Income }\end{array}$ & $\begin{array}{l}\text { Number of } \\
\text { Relatives }\end{array}$ & $\begin{array}{c}\text { Grades } \\
\text { Completed }^{2}\end{array}$ \\
\hline Credit Constrained & $\begin{array}{l}-0.666 \\
(3.523)\end{array}$ & $\begin{array}{l}-0.622 \\
(3.863)\end{array}$ & $\begin{array}{l}-0.597 \\
(4.146)\end{array}$ & $\begin{array}{l}-0.736 \\
(3.915)\end{array}$ & $\begin{array}{l}-0.632 \\
(3.326)\end{array}$ & $\begin{array}{l}-0.635 \\
(3.360)\end{array}$ \\
\hline Family Income & $\begin{array}{c}0.305 \\
(6.292)\end{array}$ & $\begin{array}{c}0.300 \\
(6.236)\end{array}$ & $\begin{array}{l}0.305 \\
(6.354)\end{array}$ & $\begin{array}{c}0.474 \\
(4.796)\end{array}$ & $\begin{array}{c}0.325 \\
(6.637)\end{array}$ & $\begin{array}{c}0.295 \\
(6.197)\end{array}$ \\
\hline $\begin{array}{l}\text { Race*Credit } \\
\text { Constrained }\end{array}$ & $\begin{array}{l}-0.611 \\
(2.078)\end{array}$ & $\begin{array}{l}-0.559 \\
(2.033)\end{array}$ & $\begin{array}{l}-0.691 \\
(2.383)\end{array}$ & $\begin{array}{l}-0.515 \\
(1.745)\end{array}$ & $\begin{array}{l}-0.582 \\
(1.973)\end{array}$ & $\begin{array}{l}-0.622 \\
(2.123)\end{array}$ \\
\hline Race*Family Income & $\begin{array}{c}0.124 \\
(0.969)\end{array}$ & $\begin{array}{c}0.110 \\
(0.863)\end{array}$ & $\begin{array}{c}0.107 \\
(0.829)\end{array}$ & $\begin{array}{c}0.427 \\
(1.688)\end{array}$ & $\begin{array}{c}0.129 \\
(1.004)\end{array}$ & $\begin{array}{c}0.110 \\
(0.866)\end{array}$ \\
\hline Inclusive Value & $\begin{array}{c}0.346 \\
(2.295) \\
\end{array}$ & $\begin{array}{c}0.382 \\
(2.581) \\
\end{array}$ & $\begin{array}{c}0.368 \\
(2.543) \\
\end{array}$ & $\begin{array}{c}0.330 \\
(2.215) \\
\end{array}$ & $\begin{array}{c}0.348 \\
(2.260) \\
\end{array}$ & $\begin{array}{c}0.370 \\
(2.913) \\
\end{array}$ \\
\hline Number of Parameters & 33 & 33 & 33 & 33 & 33 & 33 \\
\hline Log likelihood & $-2,445.66$ & $-2,446.74$ & $-2,442.67$ & $-2,457.94$ & $-2,453.86$ & $-2,441.66$ \\
\hline
\end{tabular}

1. T-statistics are based on standard errors have been generated through a Monte Carlo simulation approach.

2. The specification of the first state multinomial logit was modified to also depend upon grades completed rather than educational attainment. 
Table 6: The Effect of Eliminating Racial Differences in Equilibrium Zone Attributes

on Racial Differences in Homeownership

\begin{tabular}{l|c|c|c|c|c|c|c|c}
\hline \multirow{2}{*}{$\begin{array}{l}\text { Policy Simulation } \\
\text { Variables }\end{array}$} & \multicolumn{2}{|c|}{ Black Means adjusted to White Mean Values } & \multicolumn{3}{|c}{ White Means adjusted to Black Mean Values } \\
\cline { 2 - 8 } & $\begin{array}{c}\text { White } \\
\text { Sample }\end{array}$ & $\begin{array}{c}\text { Black } \\
\text { Sample }\end{array}$ & $\begin{array}{c}\text { Racial } \\
\text { Difference }\end{array}$ & $\begin{array}{c}\text { Change in } \\
\text { Difference }\end{array}$ & $\begin{array}{c}\text { White } \\
\text { Sample }\end{array}$ & $\begin{array}{c}\text { Black } \\
\text { Sample }\end{array}$ & $\begin{array}{c}\text { Racial } \\
\text { Difference }\end{array}$ & $\begin{array}{c}\text { Change in } \\
\text { Difference }\end{array}$ \\
\hline All Attribtues & 64.8 & 37.0 & 27.8 & 5.6 & 67.0 & 42.6 & 24.4 & 2.0 \\
Percent Black & 64.8 & 38.5 & 26.3 & 4.1 & 56.8 & 42.6 & 14.2 & -8.2 \\
Percent in Poverty & 64.8 & 66.4 & -1.6 & -22.8 & 66.4 & 42.6 & 21.8 & -0.6 \\
Amenity/Price & 64.8 & 22.8 & 42.0 & 19.8 & 76.6 & 42.6 & 32.0 & 9.6 \\
Central City & 64.8 & 40.2 & 24.6 & 2.4 & 64.1 & 42.6 & 21.5 & -0.9 \\
Equity Risk & 64.8 & 42.0 & 22.8 & 0.6 & 60.8 & 42.6 & 18.2 & -4.2 \\
\hline
\end{tabular}

1. Tract attributes are adjusted so that the mean tract attributes are the same for both whites and blacks. As a result, these predictions are based on the model that treats location as exogenous and includes location characteristics in the specification. Note that the unadjusted predictions are found in the column labeled white sample for black means adjusted and black sample for white means adjusted, the first and sixth columns, respectively. The predicted racial difference before adjustments is 22.2 percentage points. 
Table 7: The Effect of Eliminating Differences in the Role of Location on Racial Differences in Homeownership

\begin{tabular}{l|c|c|c|c|c|c|c|c}
\hline \multirow{2}{*}{$\begin{array}{l}\text { Policy Simulation } \\
\text { Variables }\end{array}$} & \multicolumn{2}{|c|}{ Black Means adjusted to White Mean Values } & \multicolumn{3}{|c}{ White Means adjusted to Black Mean Values } \\
\cline { 2 - 8 } & $\begin{array}{c}\text { White } \\
\text { Sample }\end{array}$ & $\begin{array}{c}\text { Black } \\
\text { Sample }\end{array}$ & $\begin{array}{c}\text { Racial } \\
\text { Difference }\end{array}$ & $\begin{array}{c}\text { Change in } \\
\text { Difference }\end{array}$ & $\begin{array}{c}\text { White } \\
\text { Sample }\end{array}$ & $\begin{array}{c}\text { Black } \\
\text { Sample }\end{array}$ & $\begin{array}{c}\text { Racial } \\
\text { Difference }\end{array}$ & $\begin{array}{c}\text { Change in } \\
\text { Difference }\end{array}$ \\
\hline Inclusive Value & 64.8 & 24.4 & 40.0 & 17.6 & 81.3 & 42.4 & 38.9 & 16.5 \\
Cond. Incl. Val. $^{1}$ & 64.8 & 19.9 & 44.9 & 23.5 & 80.7 & 42.4 & 38.3 & 15.9 \\
Education Level $^{2}$ & 64.8 & 44.1 & 20.7 & -1.7 & 59.0 & 42.4 & 16.6 & -5.8 \\
Marital Status & 64.8 & 41.8 & 23.0 & 0.6 & 66.3 & 42.4 & 23.9 & 1.5 \\
\hline
\end{tabular}

1. The entries in the row entitled conditional inclusive values are adjusted so that the inclusive value means are the same by race across educational and marital status categories so that the influence of location is the same by race after controlling for education and marital status.

2. The entries in the rows entitled education level and marital status are based on adjusting the educational attainment or marital status variables, respectively, so that the means are the same by race. 
Table 8: The Effect of Altering Tract Attributes on Racial Differences in Homeownership

\begin{tabular}{l|c|c|c|c|c|c|c|c}
\hline \multirow{2}{*}{$\begin{array}{l}\text { Policy Simulation } \\
\text { Variables }\end{array}$} & \multicolumn{3}{|c|}{ A 10 \% Increase in Attribute } & \multicolumn{3}{c}{ A 10\% Reduction in Standard Error } \\
\cline { 2 - 9 } & $\begin{array}{c}\text { White } \\
\text { Sample }\end{array}$ & $\begin{array}{c}\text { Black } \\
\text { Sample }\end{array}$ & $\begin{array}{c}\text { Racial } \\
\text { Difference }\end{array}$ & $\begin{array}{c}\text { Change in } \\
\text { Difference }\end{array}$ & $\begin{array}{c}\text { White } \\
\text { Sample }\end{array}$ & $\begin{array}{c}\text { Black } \\
\text { Sample }\end{array}$ & $\begin{array}{c}\text { Racial } \\
\text { Difference }\end{array}$ & $\begin{array}{c}\text { Change in } \\
\text { Difference }\end{array}$ \\
\hline Percent Black & 64.8 & 43.0 & 21.8 & -0.6 & 70.7 & 34.2 & 36.5 & 14.1 \\
Percent Poverty & 65.0 & 41.6 & 23.4 & 1.0 & 70.6 & 32.5 & 38.1 & 15.7 \\
Percent Poverty & 64.9 & 41.9 & 23.0 & 0.6 & 69.4 & 33.6 & 35.8 & 13.4 \\
Amenity/Price & 64.7 & 42.9 & 21.8 & -0.8 & 69.3 & 33.4 & 35.9 & 13.5 \\
Equity Risk & 63.8 & 43.9 & 19.9 & -2.5 & 64.3 & 36.9 & 27.4 & 5.0 \\
Equity Risk & 64.0 & 44.0 & 20.0 & -2.4 & 64.1 & 39.8 & 27.3 & 4.9 \\
\hline
\end{tabular}

1. The price level is included as a proxy for unobserved location attributes. Separate regressions indicate an empirical relationship between the price level and both percent poverty and equity risk. For example, an increase in percent poverty decreases the price level, and an increase in percent poverty holding price level fixed implies an increase in the quality of unobserved location attributes. The third and sixth rows in the table show the effect of a change in percent poverty or equity risk, respectively, in which the price level is also adjusted to hold unobserved location attributes constant. 
Table A1: Household Level First Stage Estimations ${ }^{1}$

\begin{tabular}{|c|c|c|c|c|c|}
\hline Variable Names & Tenure & $\begin{array}{c}20 \% \\
\text { Down } \\
\text { Payment }\end{array}$ & $\begin{array}{l}\text { Optimal } \\
\text { Quantity }\end{array}$ & $\begin{array}{l}\text { Non-labor } \\
\text { Income }\end{array}$ & $\begin{array}{l}\text { Housing } \\
\text { Equity }\end{array}$ \\
\hline $\begin{array}{l}\text { Race of } \\
\text { Householder }\end{array}$ & $\begin{array}{c}0.076 \\
(0.086)\end{array}$ & $\begin{array}{c}-0.213 \\
(0.148)\end{array}$ & $\begin{array}{c}-0.371 \\
(0.073)\end{array}$ & $\begin{array}{c}-0.040 \\
(0.029)\end{array}$ & $\begin{array}{c}-0.163 \\
(0.023)\end{array}$ \\
\hline $\begin{array}{l}\text { Gender of } \\
\text { Householder }\end{array}$ & $\begin{array}{c}0.036 \\
(0.058)\end{array}$ & $\begin{array}{l}-0.192 \\
(0.107)\end{array}$ & $\begin{array}{c}0.042 \\
(0.050)\end{array}$ & $\begin{array}{c}0.034 \\
(0.020)\end{array}$ & $\begin{array}{l}-0.034 \\
(0.016)\end{array}$ \\
\hline Marital Status & $\begin{array}{c}-0.099 \\
(0.186)\end{array}$ & $\begin{array}{c}-0.275 \\
(0.293)\end{array}$ & $\begin{array}{c}0.051 \\
(0.159)\end{array}$ & $\begin{array}{c}-0.069 \\
(0.062)\end{array}$ & $\begin{array}{c}-0.185 \\
(0.054)\end{array}$ \\
\hline $\begin{array}{l}\text { High School } \\
\text { Graduate }\end{array}$ & $\begin{array}{c}0.102 \\
(0.060)\end{array}$ & $\begin{array}{c}0.067 \\
(0.096)\end{array}$ & $\begin{array}{c}0.053 \\
(0.041)\end{array}$ & $\begin{array}{c}0.033 \\
(0.018)\end{array}$ & $\begin{array}{c}0.023 \\
(0.013)\end{array}$ \\
\hline College Graduate & $\begin{array}{c}0.277 \\
(0.080)\end{array}$ & $\begin{array}{c}0.113 \\
(0.121)\end{array}$ & $\begin{array}{c}0.361 \\
(0.054)\end{array}$ & $\begin{array}{c}0.092 \\
(0.025)\end{array}$ & $\begin{array}{c}0.107 \\
(0.018)\end{array}$ \\
\hline $\begin{array}{l}\text { Spouse is High } \\
\text { School Graduate }\end{array}$ & $\begin{array}{c}0.249 \\
(0.091)\end{array}$ & $\begin{array}{c}0.055 \\
(0.123)\end{array}$ & $\begin{array}{c}0.115 \\
(0.054)\end{array}$ & $\begin{array}{c}0.015 \\
(0.027)\end{array}$ & $\begin{array}{c}0.039 \\
(0.018)\end{array}$ \\
\hline $\begin{array}{l}\text { Spouse is College } \\
\text { Graduate }\end{array}$ & $\begin{array}{c}0.553 \\
(0.123)\end{array}$ & $\begin{array}{c}0.167 \\
(0.156)\end{array}$ & $\begin{array}{c}0.222 \\
(0.072)\end{array}$ & $\begin{array}{c}0.059 \\
(0.036)\end{array}$ & $\begin{array}{c}0.078 \\
(0.025)\end{array}$ \\
\hline $\begin{array}{l}\text { Age of } \\
\text { Householder }\end{array}$ & $\begin{array}{c}0.059 \\
(0.006)\end{array}$ & $\begin{array}{c}0.012 \\
(0.014)\end{array}$ & $\begin{array}{c}0.000 \\
(0.007)\end{array}$ & $\begin{array}{c}0.009 \\
(0.002)\end{array}$ & $\begin{array}{c}0.006 \\
(0.002)\end{array}$ \\
\hline $\begin{array}{l}\text { Age Squared } \\
\text { Divided by } 100\end{array}$ & $\begin{array}{c}-0.043 \\
(0.007)\end{array}$ & $\begin{array}{c}0.031 \\
(0.020)\end{array}$ & $\begin{array}{c}0.001 \\
(0.007)\end{array}$ & $\begin{array}{l}-0.008 \\
(0.002)\end{array}$ & $\begin{array}{l}-0.004 \\
(0.002)\end{array}$ \\
\hline Spouse's Age & $\begin{array}{c}0.042 \\
(0.010)\end{array}$ & $\begin{array}{c}0.015 \\
(0.016)\end{array}$ & $\begin{array}{c}0.003 \\
(0.008)\end{array}$ & $\begin{array}{c}0.002 \\
(0.003)\end{array}$ & $\begin{array}{c}0.011 \\
(0.003)\end{array}$ \\
\hline $\begin{array}{l}\text { Spouse's Age } \\
\text { Squared }\end{array}$ & $\begin{array}{l}-0.053 \\
(0.013)\end{array}$ & $\begin{array}{l}-0.016 \\
(0.024)\end{array}$ & $\begin{array}{l}-0.007 \\
(0.009)\end{array}$ & $\begin{array}{c}0.002 \\
(0.004)\end{array}$ & $\begin{array}{c}-0.011 \\
(0.003)\end{array}$ \\
\hline $\begin{array}{l}\text { Parents Present in } \\
\text { Household }\end{array}$ & $\begin{array}{c}0.778 \\
(0.209)\end{array}$ & $\begin{array}{c}0.116 \\
(0.268)\end{array}$ & $\begin{array}{c}0.256 \\
(0.123)\end{array}$ & $\begin{array}{l}-0.047 \\
(0.057)\end{array}$ & $\begin{array}{c}0.071 \\
(0.043)\end{array}$ \\
\hline $\begin{array}{l}\text { Siblings Present in } \\
\text { Household }\end{array}$ & $\begin{array}{c}0.437 \\
(0.138)\end{array}$ & $\begin{array}{c}0.224 \\
(0.261)\end{array}$ & $\begin{array}{c}0.000 \\
(0.114)\end{array}$ & $\begin{array}{c}0.062 \\
(0.041)\end{array}$ & $\begin{array}{c}0.033 \\
(0.037)\end{array}$ \\
\hline $\begin{array}{l}\text { Children Present } \\
\text { in Household }\end{array}$ & $\begin{array}{c}0.214 \\
(0.058)\end{array}$ & $\begin{array}{c}0.005 \\
(0.093)\end{array}$ & $\begin{array}{c}0.040 \\
(0.054)\end{array}$ & $\begin{array}{c}0.018 \\
(0.020)\end{array}$ & $\begin{array}{c}0.029 \\
(0.018)\end{array}$ \\
\hline $\begin{array}{l}\text { Other Family } \\
\text { Members }\end{array}$ & $\begin{array}{c}0.108 \\
(0.072)\end{array}$ & $\begin{array}{l}-0.043 \\
(0.110)\end{array}$ & $\begin{array}{l}-0.009 \\
(0.059)\end{array}$ & $\begin{array}{l}-0.012 \\
(0.022)\end{array}$ & $\begin{array}{c}0.018 \\
(0.020)\end{array}$ \\
\hline $\begin{array}{l}\text { Number of Adults } \\
\text { in Household }\end{array}$ & $\begin{array}{c}0.103 \\
(0.056)\end{array}$ & $\begin{array}{l}-0.028 \\
(0.096)\end{array}$ & $\begin{array}{c}0.042 \\
(0.055)\end{array}$ & $\begin{array}{l}-0.016 \\
(0.019)\end{array}$ & $\begin{array}{l}-0.006 \\
(0.018)\end{array}$ \\
\hline
\end{tabular}


Table A1: Household Level First Stage Estimations (Continued)

\begin{tabular}{|c|c|c|c|c|c|}
\hline Variable Names & Tenure & $\begin{array}{c}20 \% \\
\text { Down } \\
\text { Payment }\end{array}$ & $\begin{array}{l}\text { Optimal } \\
\text { Quantity }\end{array}$ & $\begin{array}{l}\text { Non-labor } \\
\text { Income }\end{array}$ & $\begin{array}{l}\text { Housing } \\
\text { Equity }\end{array}$ \\
\hline Number of Retired & $\begin{array}{c}-0.048 \\
(0.074)\end{array}$ & $\begin{array}{l}-0.076 \\
(0.119)\end{array}$ & $\begin{array}{c}-0.038 \\
(0.038)\end{array}$ & $\begin{array}{c}0.080 \\
(0.019)\end{array}$ & $\begin{array}{c}-0.015 \\
(0.013)\end{array}$ \\
\hline $\begin{array}{l}\text { Number of } \\
\text { Children }\end{array}$ & $\begin{array}{l}-0.042 \\
(0.059)\end{array}$ & $\begin{array}{l}-0.073 \\
(0.094)\end{array}$ & $\begin{array}{l}-0.034 \\
(0.055)\end{array}$ & $\begin{array}{c}0.015 \\
(0.020)\end{array}$ & $\begin{array}{l}-0.027 \\
(0.019)\end{array}$ \\
\hline $\begin{array}{l}\text { Num. of Children } \\
\text { Less than Six }\end{array}$ & $\begin{array}{c}0.101 \\
(0.050)\end{array}$ & $\begin{array}{c}0.127 \\
(0.060)\end{array}$ & $\begin{array}{c}-0.036 \\
(0.038)\end{array}$ & $\begin{array}{c}0.015 \\
(0.020)\end{array}$ & $\begin{array}{l}-0.012 \\
(0.013)\end{array}$ \\
\hline $\begin{array}{l}\text { Less than One } \\
\text { Vehicle / Adult }\end{array}$ & $\begin{array}{c}0.306 \\
(0.074)\end{array}$ & $\begin{array}{l}-0.090 \\
(0.139)\end{array}$ & $\begin{array}{c}0.146 \\
(0.055)\end{array}$ & $\begin{array}{l}-0.007 \\
(0.023)\end{array}$ & $\begin{array}{c}0.030 \\
(0.017)\end{array}$ \\
\hline $\begin{array}{l}\text { One or More } \\
\text { Vehicle / Adult }\end{array}$ & $\begin{array}{c}0.694 \\
(0.070)\end{array}$ & $\begin{array}{c}0.072 \\
(0.139)\end{array}$ & $\begin{array}{c}0.282 \\
(0.057)\end{array}$ & $\begin{array}{c}0.011 \\
(0.022)\end{array}$ & $\begin{array}{c}0.091 \\
(0.017)\end{array}$ \\
\hline $\begin{array}{l}\text { Income from } \\
\text { Business }\end{array}$ & $\begin{array}{c}0.159 \\
(0.085)\end{array}$ & $\begin{array}{c}0.089 \\
(0.101)\end{array}$ & & $\begin{array}{c}0.579 \\
(0.021)\end{array}$ & $\begin{array}{c}0.054 \\
(0.016)\end{array}$ \\
\hline $\begin{array}{l}\text { from Social } \\
\text { Security }\end{array}$ & $\begin{array}{c}0.066 \\
(0.075)\end{array}$ & $\begin{array}{c}0.211 \\
(0.111)\end{array}$ & & $\begin{array}{c}0.306 \\
(0.022)\end{array}$ & $\begin{array}{c}0.001 \\
(0.015)\end{array}$ \\
\hline from Interest & $\begin{array}{c}0.212 \\
(0.056)\end{array}$ & $\begin{array}{c}0.318 \\
(0.078)\end{array}$ & & $\begin{array}{c}0.188 \\
(0.016)\end{array}$ & $\begin{array}{c}0.081 \\
(0.011)\end{array}$ \\
\hline from Rent & $\begin{array}{c}0.664 \\
(0.102)\end{array}$ & $\begin{array}{l}-0.102 \\
(0.115)\end{array}$ & & $\begin{array}{c}0.133 \\
(0.022)\end{array}$ & $\begin{array}{c}0.033 \\
(0.017)\end{array}$ \\
\hline from Alimony & $\begin{array}{c}0.068 \\
(0.105)\end{array}$ & $\begin{array}{l}-0.314 \\
(0.149)\end{array}$ & & $\begin{array}{c}0.110 \\
(0.030)\end{array}$ & $\begin{array}{c}0.012 \\
(0.033)\end{array}$ \\
\hline from Welfare & $\begin{array}{l}-0.872 \\
(0.093)\end{array}$ & $\begin{array}{c}0.030 \\
(0.198)\end{array}$ & & $\begin{array}{c}0.159 \\
(0.027)\end{array}$ & $\begin{array}{c}0.003 \\
(0.029)\end{array}$ \\
\hline from Other & $\begin{array}{l}-0.108 \\
(0.073)\end{array}$ & $\begin{array}{l}-0.129 \\
(0.100)\end{array}$ & & $\begin{array}{c}0.106 \\
(0.022)\end{array}$ & $\begin{array}{l}-0.021 \\
(0.018)\end{array}$ \\
\hline Years in Residence & & & $\begin{array}{c}-0.010 \\
(0.004)\end{array}$ & & \\
\hline $\begin{array}{l}\text { Square of Years } \\
\text { divided by } 100\end{array}$ & & & $\begin{array}{c}0.019 \\
(0.008)\end{array}$ & & \\
\hline $\begin{array}{l}\text { Inverse Mills Ratio } \\
\text { (Tenure) }\end{array}$ & & & $\begin{array}{c}0.029 \\
(0.024)\end{array}$ & & $\begin{array}{c}0.004 \\
(0.008)\end{array}$ \\
\hline $\begin{array}{l}\text { Inverse Mills Ratio } \\
\text { (Const) }\end{array}$ & & & $\begin{array}{l}-0.369 \\
(0.161)\end{array}$ & & \\
\hline Sample Size & 5,190 & 2,915 & 2,072 & 3,315 & 1,775 \\
\hline Log likelihood & -2449.32 & -1184.40 & 0.465 & 0.374 & 0.343 \\
\hline
\end{tabular}

1. Standard errors are shown in parentheses for all tables in the appendix. 
Table A2: Individual Level First Stage Estimation

\begin{tabular}{|c|c|c|}
\hline Variable Names & Employment & Log of Labor Earnings \\
\hline Householder Male & $\begin{array}{c}0.207 \\
(0.048)\end{array}$ & $\begin{array}{c}0.107 \\
(0.088)\end{array}$ \\
\hline Marital Status & $\begin{array}{c}-0.011 \\
(0.051)\end{array}$ & $\begin{array}{l}-0.061 \\
(0.102)\end{array}$ \\
\hline High School Graduate & $\begin{array}{c}0.292 \\
(0.041)\end{array}$ & $\begin{array}{c}-0.046 \\
(0.156)\end{array}$ \\
\hline College Graduate & $\begin{array}{r}0.363 \\
(0.053)\end{array}$ & $\begin{array}{c}0.112 \\
(0.134)\end{array}$ \\
\hline Intercept Age $<18$ & $\begin{array}{c}-6.961 \\
(0.976)\end{array}$ & $\begin{array}{c}9.595 \\
(4.253)\end{array}$ \\
\hline Slope Age $<18$ & $\begin{array}{c}0.295 \\
(0.057)\end{array}$ & $\begin{array}{c}0.005 \\
(0.230)\end{array}$ \\
\hline Intercept $18<=$ Age $<23$ & $\begin{array}{l}-3.780 \\
(0.697)\end{array}$ & $\begin{array}{c}8.366 \\
(2.165)\end{array}$ \\
\hline Slope $18<=$ Age $<23$ & $\begin{array}{c}0.123 \\
(0.029)\end{array}$ & $\begin{array}{c}0.090 \\
(0.077)\end{array}$ \\
\hline Intercept $23<=$ Age $<55$ & $\begin{array}{c}-0.711 \\
(0.384)\end{array}$ & $\begin{array}{l}10.090 \\
(1.169)\end{array}$ \\
\hline Slope $23<=$ Age $<55$ & $\begin{array}{c}0.008 \\
(0.002)\end{array}$ & $\begin{array}{c}0.014 \\
(0.005)\end{array}$ \\
\hline Intercept $55<=$ Age $<65$ & $\begin{array}{c}0.241 \\
(0.787)\end{array}$ & $\begin{array}{l}10.340 \\
(2.735)\end{array}$ \\
\hline Slope $55<=$ Age $<65$ & $\begin{array}{l}-0.045 \\
(0.010)\end{array}$ & $\begin{array}{c}0.014 \\
(0.039)\end{array}$ \\
\hline Intercept $65<=$ Age & $\begin{array}{c}3.467 \\
(0.083)\end{array}$ & $\begin{array}{l}10.258 \\
(2.218)\end{array}$ \\
\hline Slope $65<=$ Age & $\begin{array}{c}-0.083 \\
(0.014)\end{array}$ & $\begin{array}{c}0.010 \\
(0.036)\end{array}$ \\
\hline Reference Person & $\begin{array}{c}0.988 \\
(0.362)\end{array}$ & $\begin{array}{l}-0.072 \\
(0.906)\end{array}$ \\
\hline Spouse of Reference Person & $\begin{array}{c}0.162 \\
(0.359)\end{array}$ & $\begin{array}{c}0.292 \\
(0.878)\end{array}$ \\
\hline Child of Reference Person & $\begin{array}{c}0.439 \\
(0.364)\end{array}$ & $\begin{array}{c}-0.164 \\
(0.893)\end{array}$ \\
\hline Parent of Reference Person & $\begin{array}{c}0.207 \\
(0.477)\end{array}$ & $\begin{array}{c}1.849 \\
(1.385)\end{array}$ \\
\hline Sibling of Reference Person & $\begin{array}{c}0.751 \\
(0.387)\end{array}$ & $\begin{array}{l}-0.385 \\
(0.942)\end{array}$ \\
\hline Other & $\begin{array}{c}0.530 \\
(0.375)\end{array}$ & $\begin{array}{l}-0.086 \\
(0.922)\end{array}$ \\
\hline
\end{tabular}


Table A2: Individual Level First Stage Estimations (Continued)

\begin{tabular}{|c|c|c|}
\hline Variable Names & Employment & Labor Earnings \\
\hline Number Adults in Household & $\begin{array}{c}0.022 \\
(0.017)\end{array}$ & $\begin{array}{c}-0.034 \\
(0.038)\end{array}$ \\
\hline \# Retired & $\begin{array}{c}0.207 \\
(0.049)\end{array}$ & $\begin{array}{l}-0.166 \\
(0.124)\end{array}$ \\
\hline \# of Children & $\begin{array}{c}-0.048 \\
(0.016)\end{array}$ & $\begin{array}{c}-0.040 \\
(0.035)\end{array}$ \\
\hline \# Kids less than Six & $\begin{array}{c}-0.182 \\
(0.031)\end{array}$ & $\begin{array}{c}0.083 \\
(0.073)\end{array}$ \\
\hline Less than One Vehicle / Adult & $\begin{array}{c}0.292 \\
(0.056)\end{array}$ & $\begin{array}{c}0.043 \\
(0.147)\end{array}$ \\
\hline One or More Vehicle / Adult & $\begin{array}{c}0.456 \\
(0.057)\end{array}$ & $\begin{array}{c}0.145 \\
(0.162)\end{array}$ \\
\hline Receives Income from Business & $\begin{array}{c}0.229 \\
(0.049)\end{array}$ & $\begin{array}{c}-2.933 \\
(0.100)\end{array}$ \\
\hline from Social Security & $\begin{array}{c}-0.452 \\
(0.047)\end{array}$ & $\begin{array}{c}0.414 \\
(0.153)\end{array}$ \\
\hline from Interest & $\begin{array}{c}-0.098 \\
(0.038)\end{array}$ & $\begin{array}{c}0.221 \\
(0.076)\end{array}$ \\
\hline from Rent & $\begin{array}{c}-0.048 \\
(0.058)\end{array}$ & $\begin{array}{c}0.213 \\
(0.116)\end{array}$ \\
\hline from Alimony & $\begin{array}{c}0.044 \\
(0.073)\end{array}$ & $\begin{array}{c}0.064 \\
(0.151)\end{array}$ \\
\hline from Welfare & $\begin{array}{c}-0.885 \\
(0.067)\end{array}$ & $\begin{array}{c}0.518 \\
(0.307)\end{array}$ \\
\hline from Other & $\begin{array}{c}-0.217 \\
(0.048)\end{array}$ & $\begin{array}{c}-0.007 \\
(0.106)\end{array}$ \\
\hline Inverse Mills Ratio (Employed) & & $\begin{array}{c}-1.820 \\
(0.391)\end{array}$ \\
\hline Sample Size & 10,842 & 5,465 \\
\hline $\mathrm{R}^{2}$ & & 0.245 \\
\hline Log likelihood & $-5,101.46$ & \\
\hline
\end{tabular}


Table A3: Estimations for Housing Price Indices

\begin{tabular}{|c|c|c|}
\hline Variable Names & Log of Housing Price & Log of Monthly Rent \\
\hline Square Feet & $\begin{array}{c}0.182 \\
(0.031)\end{array}$ & $\begin{array}{c}0.021 \\
(0.020)\end{array}$ \\
\hline Number of Bedrooms & $\begin{array}{c}0.062 \\
(0.014)\end{array}$ & $\begin{array}{c}0.035 \\
(0.014)\end{array}$ \\
\hline Number of Bathrooms & $\begin{array}{c}0.118 \\
(0.023)\end{array}$ & $\begin{array}{c}0.112 \\
(0.039)\end{array}$ \\
\hline Number of Half Baths & $\begin{array}{c}0.089 \\
(0.022)\end{array}$ & $\begin{array}{c}0.162 \\
(0.038)\end{array}$ \\
\hline Number of Dining Rooms & $\begin{array}{c}0.054 \\
(0.026)\end{array}$ & $\begin{array}{c}0.083 \\
(0.026)\end{array}$ \\
\hline Number of Living Rooms & $\begin{array}{c}0.141 \\
(0.094)\end{array}$ & \\
\hline Number of Kitchens & $\begin{array}{c}0.079 \\
(0.102)\end{array}$ & \\
\hline Number of Other Rooms & $\begin{array}{c}0.132 \\
(0.025)\end{array}$ & $\begin{array}{c}0.054 \\
(0.032)\end{array}$ \\
\hline Age of Structure & $\begin{array}{c}0.005 \\
(0.003)\end{array}$ & \\
\hline Age of Structure Squared / 100 & $\begin{array}{l}-0.007 \\
(0.003)\end{array}$ & \\
\hline Owner is First Occupant & $\begin{array}{c}0.311 \\
(0.062)\end{array}$ & \\
\hline Unit has Cellar & $\begin{array}{c}0.048 \\
(0.033)\end{array}$ & $\begin{array}{l}-0.017 \\
(0.052)\end{array}$ \\
\hline Unit has Garage & $\begin{array}{c}0.121 \\
(0.025)\end{array}$ & $\begin{array}{c}0.126 \\
(0.041)\end{array}$ \\
\hline Unit has Porch & $\begin{array}{l}-0.017 \\
(0.027)\end{array}$ & $\begin{array}{c}0.015 \\
(0.022)\end{array}$ \\
\hline Unit has Central Air & $\begin{array}{c}0.121 \\
(0.029)\end{array}$ & $\begin{array}{c}0.229 \\
(0.031)\end{array}$ \\
\hline Unit has Public Sewer & $\begin{array}{l}-0.042 \\
(0.036)\end{array}$ & $\begin{array}{l}-0.074 \\
(0.051)\end{array}$ \\
\hline Unit has Fire Place & $\begin{array}{c}0.171 \\
(0.027)\end{array}$ & $\begin{array}{c}0.173 \\
(0.045)\end{array}$ \\
\hline Single Family Attached & $\begin{array}{l}-0.158 \\
(0.034)\end{array}$ & $\begin{array}{c}0.044 \\
(0.052)\end{array}$ \\
\hline Multi-family & $\begin{array}{c}0.217 \\
(0.059)\end{array}$ & $\begin{array}{c}0.185 \\
(0.061)\end{array}$ \\
\hline Part of Utilities in Rent & & $\begin{array}{c}0.088 \\
(0.031)\end{array}$ \\
\hline Inverse Mills Ratio (Tenure) & $\begin{array}{c}0.032 \\
(0.018)\end{array}$ & $\begin{array}{c}0.024 \\
(0.015)\end{array}$ \\
\hline Sample Size & 3,009 & 2,112 \\
\hline $\mathrm{R}^{2}$ & & 0.346 \\
\hline Log likelihood & 0.506 & \\
\hline
\end{tabular}




\section{ENDNOTES}

1. Painter, Gabriel, and Meyers also examine tenure choice for Asians and Latinos. Also see Coulson (1999).

2. The importance of credit constraints was first suggested and demonstrated in a theoretical model by Zorn (1989). Hendershott, LaFayette, and Haurin (1997) recognize that households also may be credit constrained due to limited income and examine the influence of both income and down payment constraints on homeownership.

3. There also exists a large literature that examines residential location choice in order to assess the importance of commuting time and costs. For some examples see Anas and Chu (1984), Anas (1981), Lerman (1977), and Quigley (1976).

4. Gabriel and Rosenthal (1989) and Waddell (1992) both estimate multinomial logit models. See Boehm and Ihlanfeldt (1991) for a multivariate probit model of residential location choice.

5. For example, an analysis of the mortgage application data in Boston (Munnell et. al., 1996) indicates that African-American applicants have substantially higher loan to value ratios and somewhat higher housing expense to income ratios.

6. Waddell estimates a multinomial logit that includes both residential location and tenure choice, but Waddell only examines the relationship between household demographic characteristics and homeownership not the relationship between location and homeownership.

7. The Nested Logit Model, also known as Generalized Extreme Value (GEV) model, is attributed to McFadden (1978). Train (1986) pointed out that McFadden's GEV model has sometimes been mislabeled as sequential logit, which may mislead the researcher to think that the decision maker makes a sequence of choices, each of which is described by logit. However, the GEV model derived by McFadden assumes 
that the decision maker makes one choice, namely, one alternative out of the set of all possible outcome combinations.

8. Some existing studies (see Quigley (1985), for example) model the housing choice using a hierarchy where community choice is the highest level, neighborhood the next highest, and the character of the housing unit itself including rental or owner-occupied as the lowest level choice. We compare the specification used here to an alternative nesting structure in which residential location is the highest level and tenure choice is the lower level following Borsh-Supan (1987, p. 74). He suggests choosing the structure that yields the lowest value for the Akaike information Criteria (Amemiya, 1980), which is $2 *(-$ $L+k) / N$ where $L$ is the log-likelihood value for a model, $k$ is the number of parameters including any inclusive values, and $N$ is the sample size. The nesting structure with tenure choice at the top is preferred to the alternative. The detailed results of the test are provided in endnote 16.

9. The estimated location fixed effects are essentially hedonic price indices. The concept behind a price index is to measure the price level of housing services associated with a specific location. Hedonic price indices accomplish this by using a regression to control for the contribution of physical characteristics to the sales or rental price of a housing unit. Implicit in this approach is that the spatial variation in the price indices results from the locational amenities offered by each location. See Goodman (1978).

10. See Tootell (1996) and Ross and Tootell (1999) for other examples where the rent to house price ratios are used to capture equity risk. These papers use the ratio of tract median rent to tract median house price. Such a proxy will suffer from measurement error if the quality and quantity of the housing stock varies between rental and owner-occupied housing. Our equity risk proxy avoids this problem by using a hedonic price estimation to obtain a quality adjusted price of rental and owner-occupied housing. Our proxy, however, may also suffer from measurement error if the spatial distribution of rental and owner-occupied housing varies within each zone and the location quality of owner-occupied housing 
relative to rental housing varies across the zones.

11. O'Regan and Quigley (1998) also use a gravity model to create a measure of job access. They demonstrate that the gravity model provides results that are very similar to more sophisticated models that explicitly recognize that flows are count variables using a binomial or Poisson distribution.

12. The commuting time survey has not been administered as part of the metropolitan sample of the AHS since 1985, and therefore no information on work location, commuting, or mode choice is available for the AHS after that year.

13. If the reference person is married, the family educational attainment is the average of the reference individual and their spouse's educational attainment. These attainment variables are interacted with marital status. This specification outperforms a specification in which the reference person and their spouse's attainment enter separately.

14. Philadelphia is one of the few metropolitan areas sample for the American Housing Survey in which the traffic analysis zones of the 1990 Census Transportation Planning Package are coincident with either census tracts or census block groups.

15. There exists an ongoing debate as to whether housing discrimination is a substantial cause of residential segregation. This debate often hinges on whether African-American households pay more for comparable housing than white households, see Cutler, Glaeser, and Vigdor (1999). It is important to point out that our finding that African-Americans tend to reside in locations with low price levels sheds absolutely no light on this debate. Our housing price estimations only control for the physical characteristics of housing. Therefore, the white and African-American housing in this sample are not comparable because the quality of the neighborhoods may vary dramatically and these quality differences are almost certainly the cause of the price differentials, see Chambers (1992). 
16. These means are based on the average location attributes within a zone and are only intended to describe the distribution of the sample across the zones. If African-Americans are segregated within each zone, as well as across the zones, these means may understate racial differences in neighborhood quality.

17. In order to test the nesting structure, we estimate an alternative model in which residential location outcome represents the higher level choice and tenure choice is estimated conditional on location. The tenure choice model for this alternative specification conditions upon location by interacting household characteristics with the five locations attributes: percent African American, percent poverty, central city, price level, and equity risk. The model in the paper had a loglikelihood value of $-18,588$ and included 141 parameters. The alternative model had a loglikelihood value of $-18,537$ and included 280 parameters. The Akaike Information Criteria loss function yields 7.546 for the model in the paper and 7.581 for the alternative model. The model in the paper is preferred.

18. The standard errors are estimated using a Monte Carlo simulation approach because the inclusion of the predicted value for being credit constrained and the predicted inclusive value (for model III) may bias the standard errors. Specifically, 5000 samples are drawn from the analysis sample with replacement. The tenure choice model is re-estimated using these samples in order to characterize the distribution of the parameters.

19. Simulated standard errors for the inclusive value are based on the estimated Hessian from the residential location model. Specifically, a sample of 5000 parameter vectors are drawn from the estimated distribution of the parameters, and the sample of vectors are used to create a simulated sample of inclusive values.

20. These differences are quite robust to alternative specifications of the residential location model. We 
estimated many alternative models including models that omit equity risk and/or the amenity/price index, add percent households that are owner-occupants, and finally replace job access with the average commuting time between the head of household's place of work and each possible residential location. The basic results were robust to these alternative specifications.

21. It should be noted that educational attainment enters both the homeownership and the residential location models directly. Therefore, the first stage model is also re-estimated using years of education in order to create a new inclusive value.

22. In this model, the interaction of race and the constraint variable is only significant at the 10 percent level. This modification has little effect on either the white coefficients on the constraint and family income variables, or the coefficient on the inclusive value. However, the interaction between race and family income becomes significant at the 10 percent level, and the racial interactions for the income and constraint variables are jointly significant at the 5 percent level. If family income is not assumed to be exogenous, there is still evidence that the influence of financial resources on homeownership varies by race, but we cannot disentangle the effect of income from the effect of being credit constrained.

23. Of course, this result does not imply that African-Americans benefit from being in neighborhoods with a low price level and poor amenities. It is quite possible that discrimination forces some AfricanAmerican households into poor quality locations and that these households would be better off renting in a higher quality location.

24. This approach is similar to the approach used by Avery, Beeson, and Sniderman (1996). Using Home Mortgage Disclosure Act data, they estimate census tract fixed effects on the propensity of loan approval while controlling for individual level variables. In a second stage, they estimate a tract level model using the fixed effects as dependent variables and controlling for tract characteristics. 
25. Also see Artle and Varaiya (1978), Brueckner (1986), and Haurin, Hendershott, and Wachter (1997).

26. The household assets included in the dependent variable were checking, saving, and money market accounts, stocks, bonds, and cash.

27. See Follain and Jimenez (1985) for a survey. For recent work on racial differences in housing prices, see Kiel and Zabel (1996) and Chambers (1992).

28. Similar results arise using total number of commuters between the zones and the average commute times over all modes for the gravity model. 